\title{
Long intergenic non-coding RNAs: novel drivers of human lymphocyte differentiation
}

\author{
Ilaria Panzeri ${ }^{1}$, Grazisa Rossetti ${ }^{1}$, Sergio Abrignani ${ }^{1}$ and Massimiliano Pagani ${ }^{1,2}$ * \\ 1 Integrative Biology Unit, Istituto Nazionale Genetica Molecolare "Romeo ed Enrica Invernizzi," IRCCS Ospedale Maggiore Policlinico, Milano, Italy \\ ${ }^{2}$ Department of Medical Biotechnology and Translational Medicine, Università degli Studi di Milano, Milano, Italy
}

\section{Edited by: \\ Dragana Jankovic, National Institutes of Health (NIH), USA}

\section{Reviewed by:}

Christopher E. Rudd, University of Cambridge, UK

John J. Miles, Queensland Institute of Medical Research, Australia

Susan Carpenter, University of

California San Francisco, USA

\section{${ }^{*}$ Correspondence:}

Massimiliano Pagani, Integrative Biology Unit, Istituto Nazionale Genetica Molecolare "Romeo ed Enrica Invernizzi," IRCCS Ospedale Maggiore Policlinico, via Francesco Sforza 35, Milano 20122, Italy e-mail:pagani@ingm.org
Upon recognition of a foreign antigen, $\mathrm{CD}^{+}$naïve $\mathrm{T}$ lymphocytes proliferate and differentiate into subsets with distinct functions. This process is fundamental for the effective immune system function, as $\mathrm{CD} 4^{+} \mathrm{T}$ cells orchestrate both the innate and adaptive immune response. Traditionally, this differentiation event has been regarded as the acquisition of an irreversible cell fate so that memory and effector $\mathrm{CD} 4^{+} \mathrm{T}$ subsets were considered terminally differentiated cells or lineages. Consequently, these lineages are conventionally defined thanks to their prototypical set of cytokines and transcription factors. However, recent findings suggest that $\mathrm{CD} 4^{+} \mathrm{T}$ lymphocytes possess a remarkable phenotypic plasticity, as they can often re-direct their functional program depending on the milieu they encounter. Therefore, new questions are now compelling such as which are the molecular determinants underlying plasticity and stability and how the balance between these two opposite forces drives the cell fate. As already mentioned, in some cases, the mere expression of cytokines and master regulators could not fully explain lymphocytes plasticity. We should consider other layers of regulation, including epigenetic factors such as the modulation of chromatin state or the transcription of non-coding RNAs, whose high cell-specificity give a hint on their involvement in cell fate determination. In this review, we will focus on the recent advances in understanding $\mathrm{CD}^{+}{ }^{+} \mathrm{T}$ lymphocytes subsets specification from an epigenetic point of view. In particular, we will emphasize the emerging importance of non-coding RNAs as key players in these differentiation events. We will also present here new data from our laboratory highlighting the contribution of long non-coding RNAs in driving human $\mathrm{CD} 4^{+} \mathrm{T}$ lymphocytes differentiation.

Keywords: long non-coding RNAs, epigenetic regulation, lymphocyte differentiation

\section{THE REVOLUTIONS OF REGULATORY NON-CODING RNAS}

At the beginning of this century, the results of the human genome project highlighted the complexity of our genome. What emerged was that the fraction of the genome that is informative is higher than we expected. Subsequent analysis revealed that the vast majority of informative sequences does not encode for proteins. Indeed against a total of $62.1 \%$ of the human genome covered by processed transcript ( $74.7 \%$ by primary transcripts), exons of protein-coding genes cover only the $2.94 \%$ of the genome (1). From an evolutionary point of view, the genome size is in close relationship with coding potential in prokaryotes, which have haploid genomes primarily composed by protein-coding sequences $(\sim 88 \%)$. Conversely, in eukaryotes, a correlation lacks between protein-coding gene number and organismal complexity. These observations are likely explained by the evolution of a more sophisticated architecture to control gene expression that includes the expansion of non-coding regulatory RNAs (ncRNAs) (2). Thus, we should clearly reassess the centrality of protein-coding RNAs in favor of non-coding ones.

Non-coding RNAs with fundamental functions within cells are known since the discovery of the first transfer RNA (tRNA) (3) and comprise also ribosomal RNAs (rRNAs). Nonetheless, the interest toward non-coding RNAs with regulatory functions arose with the discovery of the first human micro-RNA, let-7 (4). In order to apply a theoretical framework to the transcriptome, regulatory ncRNAs are usually classified based on their dimension: "small" ncRNAs being less than 200 nucleotides in length and "long" or "large" ncRNAs (lncRNAs) ranging from more than 200 to tens of thousands of nucleotides (Table $\mathbf{1}$ ).

Further complicating the picture, $\operatorname{lncRNAs}$ seem to be the preferred substrate for the generation of small RNAs (21). This maze of non-coding transcripts was revealed also in a genome-wide identification of lncRNAs in mouse CD8 ${ }^{+}$T lymphocytes, where 18 of the identified lncRNAs appeared to overlap with annotated miRNAs and 21 with snoRNAs (37).

Both classes can be further classified according to their position relative to known sequences of the genome, like in the case of promoter-associated RNAs (PASRs) or transcription initiation small RNAs (tiRNAs). In particular, long non-coding RNAs are usually classified relative to neighboring protein-coding genes. They can be defined as "sense" if they are transcribed from the same strand of the protein-coding gene or "antisense" if the opposite is true. They can be "divergent" if their promoter and the one of the coding transcript are in close proximity and located in a head to head fashion. They can be "exonic" or "intronic" if they overlap one or more exons, or an intron of the protein-coding 
Table 1 | Major classes of short and long regulatory non-coding RNAs.

\begin{tabular}{|c|c|c|c|}
\hline ncRNA & & Length (nt) & Function \\
\hline \multicolumn{4}{|l|}{ SHORT } \\
\hline miRNAs & Micro RNAs & $21-23$ & $\begin{array}{l}\text { In animals, associate with the miRNA-induced silencing complex (RISC) and silence the } \\
\text { expression of target genes mostly post-transcriptionally }(5-7)\end{array}$ \\
\hline snoRNAs & Small nucleolar RNAs & $60-300$ & $\begin{array}{l}\text { Help the chemical modification of mRNAs, thereby influencing stability, folding, and } \\
\text { protein-interaction properties }(8,9)\end{array}$ \\
\hline snRNAs & Small nuclear RNAs & 150 & Assist splicing of introns from primary genomic transcripts $(10,11)$ \\
\hline piRNAs & Piwi-interacting RNAs & $25-33$ & $\begin{array}{l}\text { Associate with the highly conserved Piwi family of argonaute proteins and are essential for } \\
\text { retrotransposon silencing in germline, epigenetic modifications, DNA rearrangements, mRNA } \\
\text { turnover, and translational control also in soma (12-14) }\end{array}$ \\
\hline PASRs & $\begin{array}{l}\text { Promoter-associated } \\
\text { short RNAs }\end{array}$ & $22-200$ & $\begin{array}{l}\text { Enriched at the } 5^{\prime} \text { end of genes, within } 0.5 \mathrm{~kb} \text { of TSS. Can be transcribed both sense and } \\
\text { antisense. Their function and biogenesis is not fully understood }(15,16)\end{array}$ \\
\hline TASRs & $\begin{array}{l}\text { Termini-associated } \\
\text { short RNAs }\end{array}$ & $22-200$ & $\begin{array}{l}\text { Can be transcribed both sense and antisense near termination sites of protein-coding genes. } \\
\text { Their function and biogenesis is not fully understood }(15,16)\end{array}$ \\
\hline siRNAs & Short interfering RNAs & $21-23$ & $\begin{array}{l}\text { Processed from a plethora of genomic sources, both foreign (viruses) and endogenous (repetitive } \\
\text { sequences). Canonically induce the degradation of perfectly complementary target RNAs }(17,18)\end{array}$ \\
\hline tiRNAs & $\begin{array}{l}\text { Transcription initiation } \\
\text { RNAs }\end{array}$ & $15-30$ & $\begin{array}{l}\text { Enriched immediately downstream transcriptional start sites (TSSs) of highly expressed genes. } \\
\text { Their function and biogenesis is not fully understood }(16,19,20)\end{array}$ \\
\hline \multicolumn{4}{|l|}{ LONG } \\
\hline NATs & $\begin{array}{l}\text { Natural antisense } \\
\text { transcripts }\end{array}$ & $>200$ & $\begin{array}{l}\text { Transcribed from the same locus but opposite strand of the overlapping protein-coding } \\
\text { sequence. Involved in gene expression regulation, RNA editing, stability, and translation }(21,22)\end{array}$ \\
\hline PALRs & $\begin{array}{l}\text { Promoter-associated } \\
\text { long RNAs }\end{array}$ & $200-1000$ & Enriched at promoters, found to regulate gene expression $(23,24)$ \\
\hline PROMPTs & $\begin{array}{l}\text { Promoter upstream } \\
\text { transcripts }\end{array}$ & $200-600$ & $\begin{array}{l}\text { Enriched at TATA-less, CpG-rich promoters with broad TSSs. Affect promoter methylation and } \\
\text { regulate transcription (25-27) }\end{array}$ \\
\hline T-UCRs & $\begin{array}{l}\text { Transcribed } \\
\text { ultraconserved regions }\end{array}$ & $>200$ & $\begin{array}{l}\text { Perfectly conserved between human, rat, and mouse. Frequently located at fragile sites and at } \\
\text { genomic regions involved in cancer (28) }\end{array}$ \\
\hline $\begin{array}{l}\text { Intronic } \\
\text { RNAs }\end{array}$ & & $>200$ & $\begin{array}{l}\text { Transcribed from introns of overlapping protein-coding sequences. Involved in the control of } \\
\text { gene expression, alternative splicing, and source for generation of shorter regulatory RNAs (29) }\end{array}$ \\
\hline eRNAs & $\begin{array}{l}\text { Enhancer-derived } \\
\text { RNAs }\end{array}$ & $>200$ & $\begin{array}{l}\text { Function still not completely understood. May functionally contribute to the enhancer function } \\
(30-32)\end{array}$ \\
\hline LincRNAs & $\begin{array}{l}\text { Long intervening } \\
\text { (intergenic) RNAs }\end{array}$ & $>200$ & Gene expression regulation, regulation of cellular processes $(33,34)$ \\
\hline uaRNAs & 3'UTR-derived RNAs & $<1000$ & Derive within $3^{\prime}$ untranslated region (3'UTR) sequences. Function still not clearly understood (35) \\
\hline $\operatorname{circRNA}$ & Circular RNA & 100 to $>4000$ & Diverse, from templates for viral replication to transcriptional regulators (36) \\
\hline
\end{tabular}

gene respectively. Instead, they can be "intergenic" (or "intervening"; lincRNAs) if they lie within a sequence between two protein-coding genes (38). In this review, we will focus on this last category, which is probably the most studied given that the location of these lncRNAs avoids complications deriving from the overlap with other genes. The majority of known lncRNAs is generated by the same transcriptional machinery of mRNAs. This means that transcribed lincRNAs genomic sequences are marked by RNA polymerase II occupancy and histone modifications that are shared with active protein-coding genes, such as $\mathrm{H} 3 \mathrm{~K} 4 \mathrm{me} 3$ at promoters and $\mathrm{H} 3 \mathrm{~K} 36 \mathrm{me} 3$ within gene bodies (39). They are capped by methylguanosine at their $5^{\prime}$, spliced, and polyadenylated, even if the widespread representation of this last property among known lncRNAs could be partially due to the RNA sequencing strategies used for their identification (15, 40). Indeed, broader analysis identified about 39\% of lncRNAs to have at least one of the six most common poly(A) motifs, compared to $51 \%$ for coding transcripts (1). These properties imply that there are few distinctive biochemical features that allow the distinction of lncRNAs from protein-coding mRNAs. Among 
them, lncRNAs have unusual exon structure, with on average 2-5 exons. Intriguingly, lncRNAs are significantly more likely to overlap repetitive elements and particularly RNA-derived transposable elements (TEs). These last account for about 30\% of human lncRNAs nucleotides, often in proximity of their transcriptional start site (TSS), which could suggest that TEs could be important drivers of lncRNAs evolution (see below). Nonetheless, the main difference between lncRNAs and protein-coding genes relies by definition on their coding potential: lncRNAs does not possess open reading frames (ORFs), as evaluated based on: the conservation of ORFs codons (41), ORFs length, the presence of known protein domains, in vitro translation $(42,43)$, and ribosome footprinting (44) assays. However, these conceptual constraints are terribly artificial: short, non-canonical peptides have been found to arise from small ORFs within ncRNA (45-48); lncRNAs genes can also code for proteins and have a double function (49) and ultimately, the coding potential does not necessarily exclude a function as RNA also for known mRNAs (50). Evolution makes boundaries between coding and non-coding genes fainter as ncRNAs can evolve by pseudogenization. This event can follow disruption of the ancestral ORF, but not of the untranslated regulatory regions (UTRs) in protein-coding genes duplicates (50) or can arise without duplication, but from the co-option of ancestral genes to different, non-coding functions (51). This was the case of the long-known Xist RNA, involved in the silencing of the inactive $\mathrm{X}$ chromosomes in eutherians. In particular, two exons of the protein-coding gene $\operatorname{Lnx} 3$ are homologous to Xist. This gene retained a protein-coding capacity at least in the common ancestor of marsupials and placentals. Conversely, the Xist A-repeat implicated in X-silencing function is not conserved. This sequence likely arose from the insertion of a TE recruited to form a proto-Xist gene $(52,53)$. Therefore, the difference between dosage compensation in marsupials, eutherians, and monotremes can be ascribed from the presence of a Xist-independent XCI in mammalian ancestor and the peculiar evolution of the proto-Xist gene by pseudogenization in the eutherian ancestor. Intriguingly, other lncRNAs involved in X-inactivation are similarly examples of pseudogenization (54). The boundary between coding and non-coding is even less defined when ncRNAs arise from joining of coding and non-coding exons through alternative splicing $(55,56)$, from untranslated regions of mRNAs $(57,58)$ or from the opposite strand of the overlapping protein-coding gene (59). Strikingly, more than a half of protein-coding genes in mammals have a complementary non-coding transcript (60). These findings further challenge our "linear" model of the genome, prompting a re-evaluation of current dogma and genes definitions. Genomic regions indeed are far more complex than previously thought: genes can be used for different purposes and different functional elements can co-locate intermingling coding and non-coding regions.

The interest toward lncRNAs has been rapidly growing and their expressions have been quantitated in many different tissues and cell types by high-throughput sequencing (RNA-seq). These efforts retrieved catalogs with little overlap, so that the number of known lncRNAs is still growing, in contrast with the number of known protein-coding genes that has been remarkably stable over years. Indeed, IncRNAs are far more cell-specific than mRNAs, generally less but also more dynamically expressed at various differentiation stages. For this reason, immune system is an excellent context in which we can deepen our knowledge on lncRNAs. While many excellent reviews cover the recent advances in understanding the role of these molecules within the innate branch $(61,62)$, little is still known about their importance for the human adaptive immune system. Effector lymphocytes are highly specialized cells that arise from common progenitors through differentiation processes still not completely understood. Besides, lymphocytes can be purified through cell sorting from blood of healthy donors and the existence of in vitro differentiation protocols provide the ideal setting for the identification of lncRNAs expressed in the human immune system and for their functional characterization.

Indeed, the growing interest on lncRNAs and the lack of knowledge on their expression patterns in the human immune system prompted us to perform the RNA-seq analysis on 13 human primary lymphocytes subsets purified by FACS sorting from healthy donors $\left(\mathrm{CD}^{+}\right.$naïve, $\mathrm{T}_{\mathrm{H}} 1, \mathrm{~T}_{\mathrm{H}} 2, \mathrm{~T}_{\mathrm{H}} 17, \mathrm{~T}_{\mathrm{reg}}, \mathrm{T}_{\mathrm{CM}}, \mathrm{T}_{\mathrm{EM}}, \mathrm{CD}^{+}$ naïve, $\mathrm{T}_{\mathrm{CM}}, \mathrm{T}_{\mathrm{EM}}, \mathrm{B}$ naïve, $\mathrm{B}$ memory, $\mathrm{B} \mathrm{CD} 25^{+}$) and to develop a bioinformatics pipeline for lincRNAs identification.

Through this analysis, we identified long intergenic ncRNAs genes expressed in these subsets and confirmed that lincRNAs cellspecificity is higher than protein-coding genes even when comparing lincRNAs genes with membrane receptor protein-coding genes, which are generally referred as the most accurate markers for lymphocyte subsets definition. Besides, a major outcome of this analysis is the identification through de novo transcriptome reconstruction of 563 novel, previously unannotated long intergenic ncRNAs genes, increasing by $\sim 12 \%$ the number of lincRNAs known to be expressed in human lymphocytes (63). Intriguingly, a fraction of lincRNAs specific for B cells and a fraction of "pan-T" lincRNAs also exist (63). It would be extremely interesting to study these lincRNAs during lymphocytes development in order to understand their likely peculiar role in thymic or bone-marrow-derived cells development.

These observations imply that the little overlap between available catalogs is a direct consequence of lncRNAs specificity and that we could overcome this limitation only assessing lncRNAs expression in every different, highly purified cell type at different developmental stages, instead of considering tissues as a whole. Moreover, due to their specificity of expression, human lymphocytes lincRNAs that are not yet annotated in public resources would have not been identified without performing de novo transcriptome reconstruction. As mentioned before, such tissuespecificity has been linked to the enrichment of TEs in proximity to lincRNAs TSS $(64,65)$. Moreover, RNA-seq experiments performed in a human $\mathrm{CD}^{+}$naïe $\mathrm{T}$ cells in vitro differentiation time-course suggest that lincRNA-specific expression in human lymphocyte subsets is acquired during their activation-driven differentiation from naïve to memory cells (63).

These findings hint to the involvement of lymphocyte-specific lincRNAs as fine-tuners in cell fate commitment, differentiation, and maintenance of cell identity, as demonstrated by many examples in other cell types (66-68). Also, lincRNAs are functionally involved in cell growth $(69,70)$, apoptosis $(71-74)$, development (75-77), imprinting (78-80), and dosage compensation (81) in almost every cellular context (Table 2 ). 
Table 2 | Examples of lincRNAs with key roles in various cellular contexts.

\begin{tabular}{|c|c|c|}
\hline LncRNA & Cellular context & Function \\
\hline $\mathrm{H} 19$ & HSC, placenta & $\begin{array}{l}\text { Maternally expressed imprinted gene important for inhibiting placental growth (69) and maintaining adult } \\
\text { hematopoietic stem cell populations (HSC) via miR-675 generation and repression of Igf1r (70) }\end{array}$ \\
\hline GAS5 & $\begin{array}{l}\text { T lymphocytes, } \\
\text { cancers }\end{array}$ & $\begin{array}{l}\text { Plays an essential role in normal growth arrest in T lymphocytes (71). Its increased level of expression correlate with } \\
\text { cell death and reduced cell proliferation both in prostate (72) and colorectal cancer cell lines. Its lower expression is } \\
\text { instead significantly correlated with larger tumor size and poor prognosis in colorectal cancer patients (74) }\end{array}$ \\
\hline Linc-MD1 & Muscles & $\begin{array}{l}\text { Governs the timing of muscle differentiation by acting as a competing endogenous RNA (ceRNA) with respect to } \\
\text { miR-133 and miR-135 in mouse and human myoblasts (75) }\end{array}$ \\
\hline Xist & Somatic cells & $\begin{array}{l}\text { Expressed by the future inactive } X \text { chromosome, triggers gene silencing in cis by coating the chromosome. It } \\
\text { induces a cascade of chromatin changes, post-translational histone modification and DNA methylation, and leads } \\
\text { to the stable repression of X-linked genes, ensuring proper dosage compensation (81) }\end{array}$ \\
\hline KCNQ10T1 & Most tissues & $\begin{array}{l}\text { Paternally expressed antisense transcript to an interior portion of } K n c q 1 \text {, part of an imprinted locus on human } \\
\text { chromosome } 11 \mathrm{p} 15 \text {. It is critical for imprinting-mediated silencing in most tissue, via long-range intrachromosomal } \\
\text { loop and recruitment of polycomb repressive complex } 2 \text { (PRC2) (78-80) }\end{array}$ \\
\hline
\end{tabular}

Long non-coding regulatory RNAs exert their function in these fundamental processes interacting with chromatin or DNA modifiers and transcription factors (TFs) modulating gene expression (82); competing with micro-RNAs acting as sponges (83); modulating subcellular trafficking (84), translation (85), splicing (86), and likely through many other mechanisms still to be discovered (Figure 1).

Long non-coding regulatory RNAs functional flexibility derive from their intrinsic propensity to fold into thermodynamically stable secondary and higher orders structures that function as interaction modules (87). Each module can fold independently from another, forming bonds at the level of Watson-Crick, Hoogstein, and ribose face $(88,89)$. These RNAs can rapidly shift between diverse stable structural conformation, allowing allosteric transitions that can act as switches in response to environmental stimuli. They are also processed faster than mRNA, given that they must not be translated, allowing a rapid response to signals. LncRNAs can also be regulated via more than a hundred different nucleotide modifications, like in the case of tRNAs, rRNAs, and snoRNAs (90-92) that modulate their function and probably their structure. RNAs can generate multiple modules within their structure, allowing the interaction with multiple players, the reception of multiple stimuli, and the generation of multiple outputs. The required pairing is likely extremely flexible, such as in the case of micro-RNAs, and allows mismatches, bulges, and wobblings (93). Many of these interaction modules derive from repetitive elements, such as transposons that took advantage of the fewer constraints that lncRNAs sequences have compared to protein-coding genes $(1,94)$. Indeed, lncRNAs rate of sequence evolution is higher relative to protein-coding genes, even if also these transcripts exhibit evolutionary signatures of functionality. They evolve under modest but detectable selective pressure, accumulating fewer substitutions than neutrally evolving sequences $(95,96)$. Likely, conservation of relatively small units of lncRNAs sequences (estimated to be less than $5 \%$ ) could be sufficient to preserve their function, considering their already mentioned modular structure (97). This

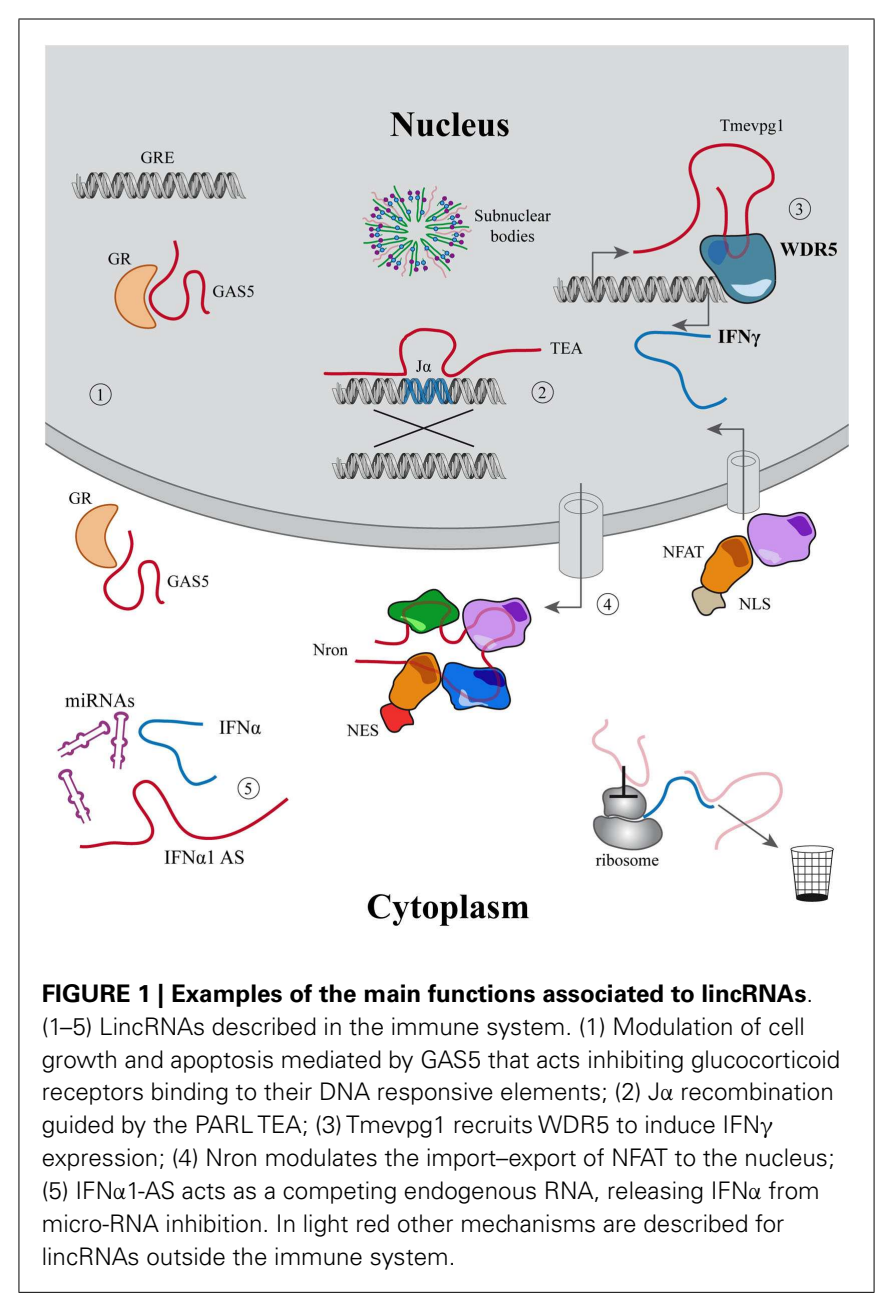

could be the reason why existing bioinformatic approaches fail to detect low level and scattered selective constraint within these loci (97). 
Through such a plastic and versatile structure, lncRNAs can exert their functions binding to proteins, other RNAs (98), and probably also DNA, even if there is still little evidence on the existence of RNA:DNA triplex $(99,100)$. In particular, lncRNAs can act as scaffolds, bridging together different molecules in a coordinated hub, like in the case of NEAT1: a highly abundant lncRNA that controls sequestration of proteins involved in the formation of paraspeckles, nuclear domains associated with mRNA retention and pathologically enriched in influenza and herpes viruses infections $(101,102)$. LncRNA can also act as guides, recruiting proteins at specific loci: this has been hypothesized in the case of recombination events that mediate genetic diversity in developing lymphocytes as class switch (CS) and V(D)J recombinations that seem to be mediated by sense and antisense transcripts that dictates the locations of combinatorial events (103-105). Again, lncRNAs can act as control devices or riboswitches in response to extracellular stimuli. For example, they can act as decoys, precluding pre-existing interactions such as GAS5 RNA that detach glucocorticoid receptor (GR) from its responsive elements in conditions of growth arrest $(106,107)$. Nonetheless, the regulatory potential of lncRNAs has been better characterized in the context of the epigenetic regulation of transcription that ultimately defines the cell transcriptome.

\section{THE ROLE OF LONG NON-CODING RNAs IN EPIGENETICS}

Histones and DNA modifications together with the tridimensional chromosomes conformation within the nucleus define, at least in part, the epigenetic landscape of the cell. This extremely dynamic context modulates gene expression and dictates the final transcriptional output in response to environmental stimuli. By definition, these modifications are then propagated throughout cell divisions. This process is important in every moment of cell life, but particularly during differentiation. Indeed, every cell within our body harbor the same genome, but every cell acquires a particular phenotype according to intrinsic and extrinsic cues that ultimately defines its epigenome and therefore its fate during differentiation. Epigenetics also defines to what extent this fate can be irreversible or plastic (108-110).

As mentioned before, human lymphocytes are an interesting model system for understanding the basis of cell fate specification and plasticity. Indeed, although traditionally the broad range of effector lymphocytes has been referred to as composed by distinct lineages, it has become increasingly clear that these cells also have notable features of plasticity. Differentiation of naïve cells into specific helper subsets requires the integration of extrinsic cues that converge into cell-intrinsic changes in the epigenetic landscape on the genome $(111,112)$. The interest within the field has been focused on the regulation of prototypical cytokine genes for each subset such as Ifng gene for $\mathrm{T}_{\mathrm{H}} 1$ or Il-4 for $\mathrm{T}_{\mathrm{H}} 2 \mathrm{CD}^{+}$lymphocytes. Much work has been done in both cases to define the complex genetic structure of these loci and the cis regulatory elements bound by TFs and chromatin modifiers promoting or repressing their transcription (113-115). The importance of the setting of epigenetic memory at these fundamental loci was underlined also by treatment with DNA methylation inhibitors $(116,117)$ or histones deacetylases inhibitors (118-120) and by deletion of DNA methyltransferase
(121-123), which caused respectively: constitutive production of IFN- $\gamma$, enhanced production of both $\mathrm{T}_{\mathrm{H}} 1$ and $\mathrm{T}_{\mathrm{H}} 2$ prototypic cytokines, and inability to activate the proper pattern of expressed cytokines. The same is true for deletion of components of trithorax group (TrxG) or polycomb repressive complex (PRC) that dictates active or repressive epigenetic marks at fundamental loci for proper T-helper cell differentiation, such as $\mathrm{Il}-4, \mathrm{Il}-5, \mathrm{Il}-13$, and Gata3 (124-129). The pattern of chromatin marks is conventional for signature cytokines: active marks are present at prototypical cytokines whereas repressive marks restrain the expression of antagonistic molecules. However, master regulators and other TFs, usually considered as definers of lineage-specific identity, are characterized by bivalent poised domains, in which both active and repressive chromatin marks are present $(130,131)$. This histone epigenetic status is peculiar also to promoters in embryonic stem cells, where it poises the expression of key developmental genes thus allowing their timely activation in the presence of differentiation signals and concomitantly precluding expression in their absence (132). Indeed, while the expression of master TFs is quite rapid, cell divisions are required for cytokine loci to become accessible or conversely repressed. Indeed, GATA3 and T-bet/STAT proteins initiate the epigenetic changes at IFN- $\gamma$ and IL-4 loci that follow the initial activation of naïve $\mathrm{T}$ cells and differentiation toward $\mathrm{T}_{\mathrm{H}} 1$ and $\mathrm{T}_{\mathrm{H}} 2$ cell fate $(133,134)$. These observations imply that T-helper cells harbor both clear-cut and plastic epigenetic marks. Nonetheless, we must consider that even cytokines genes that are clearly defined epigenetically, can be expressed or repressed in unexpected context, as reported in $\mathrm{T}_{\mathrm{H}} 1$ cells converted in IL-4-producing cells during strong $\mathrm{T}_{\mathrm{H}} 2$-polarizing helminth infections (135) or stable $\mathrm{T}_{\mathrm{H}} 1 / \mathrm{T}_{\mathrm{H}} 2$ hybrid cells derived after parasite infections (136). Therefore, other players must be involved to define the degree of plasticity of lymphocytes in response to these ever-changing environmental conditions during differentiation.

Long non-coding regulatory RNAs have been linked to epigenetic control of gene expression since the first studies regarding the already mentioned Xist transcript, involved in X chromosome inactivation in eutherians. Many other lncRNAs have been associated to chromatin or DNA modifiers and even TFs, thanks to specific mechanistic studies or high-throughput screenings (82, 137-139). This interplay can be observed across a broad range of eukaryotic organisms, suggesting that the epigenetic role of lncRNAs is conserved, even if their mere sequence conservation is often limited (as described previously). It seems that lncRNAs could act as scaffolds, physically associating with proteins that modify chromatin either activating or repressing gene expression. Thanks to the already discussed structural properties of RNA, lncRNAs could organize multiple players in spatially and temporally concerted actions (138). Not only: thanks to their ability to base pair with other nucleic acids, they could recruit these modifiers at specific loci, therefore conferring them specificity of action (98). This property has been an unsolved issue, given that chromatin modifiers do not possess intrinsic bias toward consensus sequences, at least in mammals, while in Drosophila these "docking sites" are well defined $(140,141)$. Interestingly, while many of these enzymes lack DNA-binding properties, they instead possess RNA-binding motifs (142-144). 
The majority of reported lncRNAs are involved in the repression of gene transcription, in particular by interacting with polycomb group $(\mathrm{PcG})$ proteins. The first examples of a direct interaction with PRC2 are the already mentioned Xist (145) and Kcnq1ot1, expressed only in the mammalian paternal chromosome and involved in the silencing of 8-10 protein-coding genes (146). In both these cases, IncRNAs are strictly required for the enrichment of PRC2-associated proteins and for the trimethylation of the lysine 27 of histone $\mathrm{H} 3$ at specific loci. Furthermore, other lncRNAs such as NEAT2 and TUG1 promote relocation of growth-control genes at foci of PcG proteins (called PcG bodies), therefore likely facilitating the concerted repression/activation of the transcription units in response to mitogenic signal (147). Many other protein complexes have been found to interact with lncRNAs, the majority targeting histones, either methylases or demethylases, but other involved in DNA methylation (148). Indeed, lncRNAs can bind proteins part of the TrxG (68) that antagonize PcG-mediated silencing (149). Interestingly, an antisense lncRNA has been recently involved in recruiting a regulator of DNA demethylation at a specific promoter (150). This process remains still largely unknown and it has only recently been associated to active enzymatic reactions, via TET family of methylcytosine dioxygenases $(151,152)$. Even in this case, one of the unsolved questions has been how locus-specificity can be achieved. Particularly, DNA demethylation is often restricted to few dinucleotides at the TSS. The precise mechanism, though, through which lncRNAs could direct DNA or chromatin modification has never been described. Indeed in all reported examples, correlations have been described between IncRNA-modifiers associations and loss of modification after lncRNA gene silencing.

Long non-coding regulatory RNAs are supposed to confer binding specificity to modifiers and recruiting them either in cis or in trans. In the first case, lncRNAs could act directly on sites where they are synthesized without needing to leave DNA. The current hypothesis suggests that the $5^{\prime}$ region of the nascent transcript could bind proteins while the $3^{\prime}$ is transcriptionally lagging, being still tethered to chromatin by RNA polymerase (153). This model is particularly intriguing as through this mechanism, lncRNAs could exert an allele-specific effect, like in the well-studied case of Xist. In trans regulation is instead achieved when lncRNAs act modulating genes across great distances or even on different chromosomes (154). Regarding this dichotomy, we must underline once again its artificiality. Indeed, chromosomes fold into complex, three-dimensional territories together with specialized subnuclear bodies. Proteins that are part of the transcriptional or splicing machinery and regulators of these processes group at these foci $(155,156)$. These structures are not static, but on the contrary, large-scale chromosomal repositioning is observed in response to environmental stimuli or during differentiation (157, 158). Subnuclear movements are of key importance in regulating events like transcription and rearrangement that occur at immunoglobulin loci during B lymphocytes development (159). The dynamic folding of the genome into higher order structure encompasses loci belonging to the same chromosome, even hundreds of kilobases apart, or different ones, bringing together regions that are distant if we consider the genome as linear. Therefore, in this context, it is extremely difficult to discern what regulations are in cis or in trans, especially when they involve long distance interactions. Intriguingly, lincRNAs have been found to regulate the formation of subnuclear structures, such as NEAT1, required for paraspeckles nucleation (101). LncRNAs can also affect directly the three-dimensional organization of chromosomes enhancing the function of proteins involved in looping formation, like the insulator protein CTCF (160). There are also many examples of lncRNAs involved in three-dimensional local chromatin looping that brings together the ncRNA gene with the region that it regulates within the same chromosome $(68,161)$. Recently, a lincRNA called Firre has been shown to recruit specific gene loci located on different chromosomes, acting as a docking station for organizing trans-chromosomal associations. Consistently, genetic deletion of Firre leads to a loss of proximity of several trans-interactions (162). A peculiar type of IncRNA has been described that is transcribed from enhancer regions (eRNAs). Classic enhancer elements therefore likely act through transcription of these lncRNAs that upregulate expression at promoters via the recruitment of Mediator complex $(163,164)$. Finally, there is increasing evidence that even promoters could be transcribed (165), producing lncRNAs probably involved in the enhancer-promoter loop that was hypothesized years ago but never fully resolved (166).

\section{LONG NON-CODING RNAs IN THE ADAPTIVE IMIMUNE SYSTEM}

The adaptive immune system is an extraordinary context for the study of the role of lincRNAs in differentiation. Indeed, upon antigen stimulation, naïve $\mathrm{CD}^{+}{ }^{+} \mathrm{T}$ cells differentiate into distinct T-helper subsets that were traditionally considered lineages and defined by a prototypic set of expressed cytokines and master TFs. Recently, this relative simple scenario, although useful, has been subjected to debate. $\mathrm{CD}^{+}{ }^{+} \mathrm{T}$ cells demonstrated to exhibit substantial plasticity and it has become increasingly clear that they can change the pattern of cytokines and TFs according to the milieu they encounter through their life $(167,168)$. Not only, in some cases, they can concomitantly express other cytokines and TFs together with their prototypical set. Best examples include IL-10, once thought to specifically identify $\mathrm{T}_{\mathrm{H}} 2$ and now known to be produced also by $\mathrm{T}_{\mathrm{H}} 1, \mathrm{~T}_{\text {reg }}$, and $\mathrm{T}_{\mathrm{H}} 17$ cells (169) and IFN- $\gamma$, the classic $\mathrm{T}_{\mathrm{H}} 1$ cytokine, frequently released by $\mathrm{T}_{\mathrm{H}} 17$ cells simultaneously with IL-17 (170, 171). Regarding master TFs, $\mathrm{T}_{\text {regs }}$ can express Foxp3 (their prototypical TF), but also ROR $\gamma t\left(\mathrm{~T}_{\mathrm{H}} 17 \mathrm{TF}\right)$ and Runx3 (172-174); similarly $\mathrm{T}_{\mathrm{FH}}$ cells can differentiate from FOXP3 positive cells also expressing Bcl6 (their specific TF) $(175,176)$. In this context, lncRNAs have a fundamental role in governing flexibility and plasticity or maintenance of cell identity, together with lineage-specific TFs and other ncRNAs. In particular, what is emerging from the literature is that ncRNAs typically act as fine-tuners of fate choices and this seems to be true not only in the immune system. Nonetheless, in the case of $\mathrm{CD} 4^{+} \mathrm{T}$-cell subsets that are specified but not fully determined, subtle changes in extrinsic signals can reverberate through responsive ncRNAs inducing changes that alter cell phenotype $(38,177,178)$. Usually, the stability of lineage identity is achieved through the implementation and inheritance of epigenetic modification, but as mentioned before, lncRNAs can act directly on histone and DNA modifiers redefining this context. 
Conversely, lncRNAs can also buffer this situation in other conditions, acting as maintainers of cell identity. In the cellular system, lncRNAs can be regarded as minor nodes in a huge interconnected network (179), as they usually interact with few other players. This condition allows them to be more flexible and sensitive to variations without disrupting the whole network integrity (180). This is true both over a very short period, as cells can easily and rapidly adapt to environment, and also over long evolutionary periods, as lncRNAs are among the fastest evolving sequences in the genome $(95,181-183)$. Conversely, master transcription regulators can be considered highly connected hubs, which confer robustness to the network. Indeed, very few protein-coding genes have been lost from worms to human and mutations are most often pathological $(184,185)$.
Several single-case or genome-wide studies on lncRNAs in the murine adaptive immune system or cell lines are now available in the literature, whereas only few studies have been conducted until now in the human context. The number of studies that unveiled the function and mechanism of a specific lncRNA is so small that can be counted on one hand (Table 3 ).

The importance of the studies in the human immune system is underlined by the fact that the differences between experimental animal models and human are still subject of debate in terms of immunologic responses (199-201). Moreover, there are increasing evidences that ncRNAs are poorly conserved between animal models and human $(202,203)$. In particular, lncRNAs are really fastevolving elements as demonstrated by the fact that over $80 \%$ of the human lncRNAs that arose in the primate lineage, only $3 \%$ are

Table 3 | Studies on IncRNAs in the adaptive immune system

\begin{tabular}{|c|c|c|}
\hline Sample & LncRNAs & Function \\
\hline $\begin{array}{l}\text { Granulocytes, monocytes, } N K, B \text {, naïve } \\
C D 8^{+} \text {and } C D 4^{+} \text {, memory human } T \text { cells; } \\
\text { in vitro polarized precursors } T \text {-helper, } \mathrm{T}_{\mathrm{H}} 0 \text {, } \\
\mathrm{T}_{\mathrm{H}} 1 \text {, and } \mathrm{T}_{\mathrm{H}} 2 \text { human cells }\end{array}$ & $\begin{array}{l}240 \text { IncRNAs associated with } \\
\text { autoimmune disease (AID) } \\
\text { loci (RNA-seq) }\end{array}$ & $\begin{array}{l}\text { Analysis of the expression profile of the AID-associated IncRNAs } \\
\text { (186) }\end{array}$ \\
\hline $\begin{array}{l}\mathrm{CD}^{-} \mathrm{CD}^{-}, \mathrm{CD}^{+}{ }^{+} \mathrm{CD} 8^{+}, \mathrm{CD}^{+}{ }^{+} \mathrm{CD} 8^{-} \\
\text {activated } \mathrm{CD}^{+}{ }^{+} \text {mouse } \mathrm{T} \text { cells }\end{array}$ & $\begin{array}{l}31423 \text { IncRNAs (IncRNA } \\
\text { microarray) }\end{array}$ & Expression analysis and prediction of function (187) \\
\hline 17 T-cell leukemia cell lines & $\begin{array}{l}\text { Thy-ncR } 1 \text { (expression profiling } \\
\text { of } 10 \text { thymus-specific ncRNA) }\end{array}$ & $\begin{array}{l}\text { Enriched in human immature cells; acts as a cytoplasmic } \\
\text { riboregulator that reduces the level of MFAP4 mRNA (188) }\end{array}$ \\
\hline $\begin{array}{l}\text { Naïve, memory, activated, non-activated } \\
\text { mouse } \mathrm{CD}^{+} \mathrm{T} \text { cells }\end{array}$ & $\begin{array}{l}\text { Over } 1000 \text { mouse and human } \\
\text { IncRNAs (microarray) }\end{array}$ & Expression and conservation analysis (37) \\
\hline $\begin{array}{l}\mathrm{CD}^{-} \mathrm{CD}^{-}, \mathrm{CD}^{+}{ }^{+} \mathrm{CD} 8^{+}, \mathrm{CD}^{+}, \mathrm{CD}^{+} \\
\text {mouse thymic } \mathrm{T} \text { cells, and thymus-derived } \\
\mathrm{T}_{\text {reg }} \text { cells. In vitro differentiated } \mathrm{T}_{\mathrm{H}} 1, \mathrm{~T}_{\mathrm{H}} 2 \text {, } \\
\mathrm{T}_{\mathrm{H}} 17 \text {, and induced } \mathrm{T}_{\text {reg }}\end{array}$ & $\begin{array}{l}1524 \text { lincRNA genes } \\
\text { (RNA-seq); LincR-Ccr2-5'AS }\end{array}$ & $\begin{array}{l}\text { Expression analysis and ChIP-seq data analysis to identify lincRNA } \\
\text { genes and possible regulators. LincR-Ccr2-5'AS is } T_{H} 2 \text {-specific and } \\
\text { reduces the expression of } C c r 1, C c r 2, C c r 3 \text {, and } C \text { Cr5. It contributes } \\
\text { to the migration of } T_{H} 2 \text { cells (189) }\end{array}$ \\
\hline Infected Namalwa B lymphocytes & IFNA1-AS & $\begin{array}{l}\text { Cytoplasmic post-transcriptional stabilization of IFN- } \alpha 1 \text { RNA masking } \\
\text { a miRNA-binding site (190) }\end{array}$ \\
\hline $\begin{array}{l}\text { Jurkat cells, primary lymphomas, } \\
\text { lymphoma cell lines, CD19+ B cells }\end{array}$ & Saf/FAS-AS1 & $\begin{array}{l}\text { Regulates the alternative splicing of Fas which is impaired in } \\
\text { non-Hodgkin's lymphomas associated with poor prognosis }(191,192\end{array}$ \\
\hline Activated human $\mathrm{CD} 4^{+} \mathrm{T}$ cells & BIC RNA (EST library analysis) & $\begin{array}{l}\text { Proto-oncogene, induced upon activation, sensitive to } \\
\text { immunosuppressive drugs (193) }\end{array}$ \\
\hline Jurkat cells & $\begin{array}{l}\text { NRON (shRNA knock-down } \\
\text { screening) }\end{array}$ & $\begin{array}{l}\text { Regulates NFAT subcellular localization as part of an RNA-protein } \\
\text { complex (84) }\end{array}$ \\
\hline $\begin{array}{l}\text { CEM-C7 CKM1, jurkat JKM1, human } \\
\text { primary lymphocytes }\end{array}$ & GAS5 & $\begin{array}{l}\text { Necessary and sufficient for growth arrest. Acts competing from } \\
\text { GREs }(71,106)\end{array}$ \\
\hline Human $\mathrm{CD}^{+}{ }^{+}, \mathrm{CD}^{+}$cells, PBMC & NTT & Unknown, it shows a similar expression pattern to IFN $\gamma R$ (194) \\
\hline Thymocytes & TEA & Instruct the activity of $J \alpha$ promoters and recombination $(103,195)$ \\
\hline Human $T_{H} 1$ cells & NeST/Tmevpg1/IFNG-AS1 & $\begin{array}{l}\text { Dependent on STAT4, T-bet, and NFKB. Contributes to Ifng } \\
\text { expression by binding WDR5 and alter H3K4me3 }(196,197)\end{array}$ \\
\hline Human primary $\mathrm{CD}^{+}$and $\mathrm{CD}^{+} \mathrm{T}$ cells, & GATA3-AS1 & Specifically expressed in $T_{H} 2$ cells (198) \\
\hline
\end{tabular}

primary and polarized (from $\mathrm{CD}_{4}{ }^{+}$and

$\mathrm{CD}^{+}{ }^{+}$) $\mathrm{CD}^{+} \mathrm{CM}, \mathrm{T}_{\mathrm{H}} 1, \mathrm{~T}_{\mathrm{H}} 2, \mathrm{~T}_{\mathrm{H}} 17$, and

$\mathrm{T}_{\text {reg }}$ cells; neutrophils, basophils, $\mathrm{CD} 8^{+}$

$\mathrm{CM}, \mathrm{B}$ cells 
conserved across tetrapods and most mammalian lncRNAs lack known orthologs outside vertebrates (97). In detail, even between mouse and human, lncRNAs are poorly conserved (204-206). Despite their rapid evolution, lncRNAs are selected more than neutral sequences and in particular more than intergenic regions, but significantly less than mRNAs $(96,97,207)$. It must be underlined that the conservation rate reported could be overestimated: substitution rates are derived from whole-genome alignment and based on the assumption that even segment of homologies imply that that segment belongs to the same RNA class, but this is not necessarily the case. Indeed, it could be that in another genome context a specific lncRNA gene segment is transcribed and processed as part of a protein-coding RNA (208). A striking example is Hotair that is involved in the regulation of the highly conserved cluster of Hox genes (68). The human lincRNA is conserved in the mouse genome (209), nonetheless only the $3^{\prime}$ region is effectively part of the murine homolog (183). The importance of studying lincRNAs specifically within the human immune system derives from these considerations, but this field is still poorly investigated. The majority of the studies focused on the innate immune system (210-212) or analyzed pathological situations, such as cancerrelated lncRNAs $(192,213)$ or responses to specific infections (102, 214-216), mostly in mice. The first functional study that focused on the adaptive immune system, and in particular on $\mathrm{T}_{\mathrm{H}} 1$ and $\mathrm{T}_{\mathrm{H}} 2$ lymphocytes, involved a lincRNA, Tmevpg1, that is selectively expressed in $\mathrm{T}_{\mathrm{H}} 1$ cells via STAT4 and T-bet, both in mouse and human. It participates in the induction of IFN- $\gamma$ expression strictly in response to $\mathrm{T}_{\mathrm{H}} 1$ differentiation program and not in other cellular contexts. These results highlight once again the complexity of gene expression regulatory network and the specificity of action of lincRNAs (196). Another paper described a lincRNA, GATA3-AS1, specifically expressed in primary $\mathrm{T}_{\mathrm{H}} 2$ cells and hypothesized its co-regulation with GATA3 (198). GAS5, expressed in human Tlymphocytes, is degraded in optimal growth conditions, but it accumulates contributing to growth arrest in starving conditions (107). In this situation, it competes with GRs DNA-binding sequences, suppressing GR-mediated transcription (106). Broader studies have been performed on the CD8 ${ }^{+} \mathrm{T}$ cell transcriptome (37), and recently on $\mathrm{CD}^{+} \mathrm{T}$ lymphocytes (189), but still on mice models. In $\mathrm{B}$ cells, chromatin remodeling associated with $\mathrm{V}(\mathrm{D}) \mathrm{J}$ recombination has been potentially linked to a widespread antisense intergenic transcription that occurs in the variable (V) region of the immunoglobulin heavy chain (Igh) locus $(104,105)$. So far, no studies have been published that performed a deep transcriptomic analysis on human primary lymphocytes from healthy donors, identifying lncRNAs fundamental for differentiation processes. These few examples are just clues of the importance that lincRNA could have for the proper function also of the human immune system and prompt to a deeper analysis of their role in this particularly intriguing context.

\section{LONG NON-CODING RNAS AS EPIGENETIC MODULATORS IN LYMPHOCYTE DIFFERENTIATION}

Traditionally, the secretion of IFN- $\gamma$ and TNF- $\alpha$ characterizes $\mathrm{T}_{\mathrm{H}} 1$ lymphocytes, whereas IL-4, IL-5, and IL-13 are considered prototypic cytokines secreted by $\mathrm{T}_{\mathrm{H}} 2$ cells. According to this classic paradigm, these differences underline the different functions exerted by these lymphocytes: $\mathrm{T}_{\mathrm{H}} 1$ are considered as important to eliminate intracellular bacteria and viruses, whereas $\mathrm{T}_{\mathrm{H}} 2$ to resist parasitic infections (217). The advantage of solid in vitro differentiation protocols allowed a deep understanding of the genetic mechanisms governing these cells. Since the discovery of this dichotomy, other cell subsets have been identified, but this $\mathrm{T}_{\mathrm{H}} 1 / \mathrm{T}_{\mathrm{H}} 2$ paradigm was undoubtedly useful. Therefore, it is not a case that among the few lncRNAs identified in the immune system, many of those functionally characterized have been described in these two cell subsets. Nevertheless as mentioned before, just one lincRNA, Tmevpg1 (also known as NeST or IFNG-AS1) has been characterized in deep. Tmevpg1 is located proximal to IFN$\gamma$ gene both in mice and humans, antisense and convergently transcribed respect to the neighboring gene and plays a role in chromatin remodeling. This transcript is a $\mathrm{T}_{\mathrm{H}} 1$-specific lincRNA: it requires STAT4 and T-bet for being transcribed and is also bound by CTCF and cohesin during lineage-specific induction (196). Therefore, Tmevpg1 is directly dependent on the activation of a $\mathrm{T}_{\mathrm{H}}$ 1-polarizing transcriptional program, in which the presence of IL-12 leads to the activation of the JAK/STAT pathway via STAT4 (and STAT1) that induces the expression of T-bet. Interestingly, Tmevpg1 gene harbor sequences regulated by histone acetylation and DNase I hypersensitive sites found in $\mathrm{T}_{\mathrm{H}} 1$ but not $\mathrm{T}_{\mathrm{H}} 2$ cells $(218,219)$. Tmevpg1, in its turn, plays a direct part in defining the proper $\mathrm{T}_{\mathrm{H}} 1$ cytokine expression pattern, influencing Ifng transcription in the presence of T-bet (196), via H3K4 trimethylation by WDR5 binding in mice models (197).

Given the increasing number of lncRNAs described in different cellular contexts and the high number of specific lincRNAs expressed in the different lymphocytes subsets identified with the aforementioned RNA-seq analysis, many more lincRNAs will likely be characterized in the future with a relevant function in the human immune system. A major limitation, though, in the studies on lncRNAs is that there is little biological knowledge on the biochemical or molecular function of lncRNA genes. Compared to classical protein-coding gene studies, hints on their functions cannot be gained simply by the analysis of their primary sequence and application of computational methods to infer lncRNA function are also still in their infancy. As lincRNAs have been reported to influence the expression of neighboring genes $(25,26,28,39)$, one possible approach to investigate their putative function is to focus on lymphocyte lincRNAs proximal to protein-coding genes involved in key cell-functions.

Through this approach, we identified a $\mathrm{T}_{\mathrm{H}} 1$-specific lincRNA that localized $\sim 140 \mathrm{~kb}$ upstream to $M A F$ that was therefore called linc-MAF-4. MAF is a TF involved in $\mathrm{T}_{\mathrm{H}} 2$ differentiation and required for the efficient secretion of IL- 4 by $\mathrm{T}_{\mathrm{H}} 17$ and the proper development of $\mathrm{T}_{\mathrm{FH}}$ cells (220-222). Intriguingly, the expression of linc-MAF-4 is negatively correlated with respect to the expression of MAF: linc-MAF-4 expression is high and specific in $\mathrm{T}_{\mathrm{H}} 1$ lymphocytes, where $M A F$ is lowly expressed whereas in $\mathrm{T}_{\mathrm{H}} 2$ cells the expression of linc-MAF-4 is extremely low and $M A F$ is highly expressed. Coherently, linc-MAF-4 knock-down in naïve $\mathrm{CD} 4^{+} \mathrm{T}$ cells increased the expression of MAF and interestingly induced a more general skewing of the whole transcriptomic profile of these cells toward a $\mathrm{T}_{\mathrm{H}} 2$-like fate (63). The regulation exerted by lincMAF-4 on MAF gene was analyzed in more detail and this lincRNA 


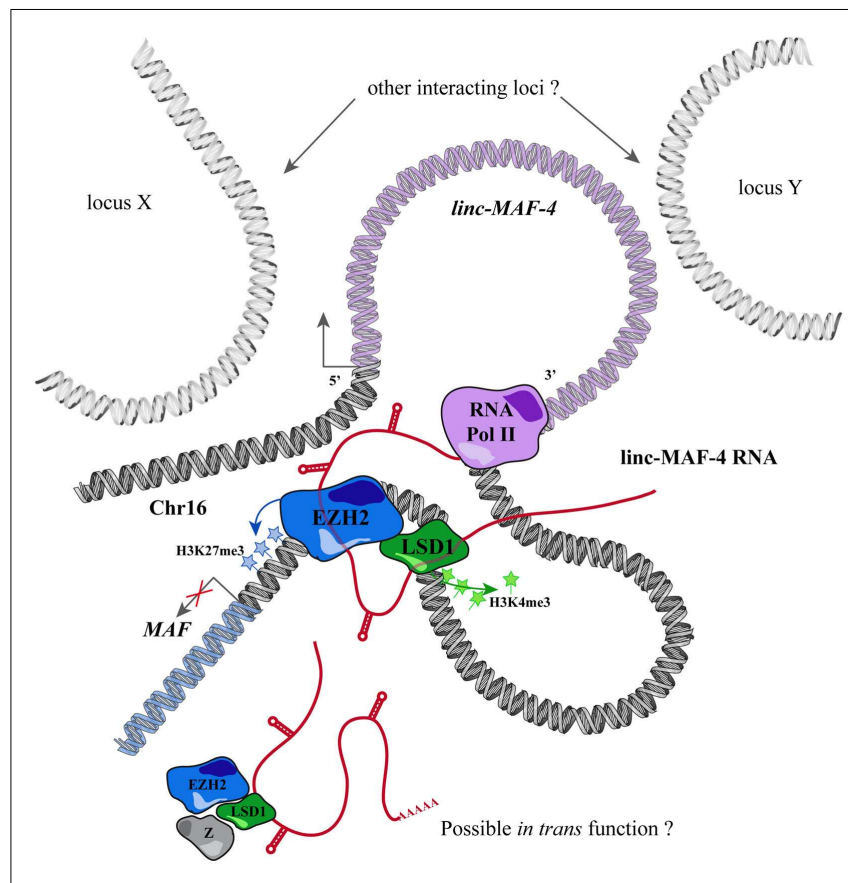

FIGURE 2 | Mechanism of action proposed for linc-MAF-4.

proved to modulate $M A F$ expression in cis, as hypothesized by expression analysis. Linc-MAF-4 exerts this regulation by exploiting a chromatin loop that brings its genomic region close to the promoter of $M A F$ gene. Indeed, the chromatin organization of this region allows linc-MAF-4 transcript to recruit chromatin remodelers that inhibit MAF transcription. In particular, linc-MAF-4 was found to associate with EZH2, key enzymatic subunit of the PRC2 complex, and LSD1. These proteins methylate H3K27 and demethylate $\mathrm{H} 3 \mathrm{~K} 4$, respectively: two histones modifications that code for transcriptional repression. (63). A similar mechanism was described for other lincRNAs, such as HOTAIR and MEG3 (154, 223) but never before for other lncRNAs expressed in the adaptive immune system (Figure 2).

Changes of lincRNAs expression during naïve to memory $\mathrm{CD}^{+}$T-cell differentiation (37) and during naïve $\mathrm{CD} 4^{+} \mathrm{T}$ cells differentiation into distinct helper T-cell lineages (189) have been described in the mouse immune system. linc-MAF-4, though, is, to our knowledge, the first example of a lincRNA playing a role in the proper differentiation of human $\mathrm{T}_{\mathrm{H}} 1$ cells, suggesting that, besides cytokines and TFs, lncRNAs take part in the $\mathrm{T}_{\mathrm{H}} 1$ differentiation program as already shown in many other cell types. At this point, an obvious question arises: to what extent are these cells plastic? These findings are evidences that it is possible to redirect the differentiation path of naïve $\mathrm{CD} 4^{+} \mathrm{T}$ cells acting on their lincRNA content. Nevertheless, could it be possible to modulate already committed cells? We would expect that the mere downregulation of a lincRNA would not be sufficient nor a lincRNA knock-out: as mentioned before, lincRNAs are minor nodes in a huge interconnected network composed by feedback mechanisms and epigenetic marks that act stabilizing a pre-existent differentiation status. However, a modulation in lincRNA content may be sufficient to make these cells more responsive to environmental cues that could overcome stabilizing forces, inducing a sort of trans-differentiation event. Functional characterization of other lncRNAs is required to address this crucial issue and to assess the extent of their contribution to cell differentiation and to the maintenance of cell identity in human lymphocytes. Based on what we discussed so far on lncRNA functions and cell-specificity, we believe that future studies will show how these molecules could be capitalized as new molecular targets for the development of novel and highly specific therapies for diseases, such as autoimmunity, immunodeficiencies, allergy, and cancer.

\section{ACKNOWLEDGMENTS}

We thank V. Ranzani for support in figures preparation and for discussions and critical revision of the manuscript. Supported by Consiglio Nazionale delle Ricerche - Ministero dell'Istruzione dell'Universita e della Ricerca (EPIGEN), Fondazione Cariplo (2013-0955), AIRC Associazione Italiana per la Ricerca sul Cancro (IG2013-ID14596), the European Research Council (269022 to SA; 617978 to MP), and Fondazione Romeo ed Enrica Invernizzi.

\section{REFERENCES}

1. Derrien T, Johnson R, Bussotti G, Tanzer A, Djebali S, Tilgner H, et al. The GENCODE v7 catalog of human long noncoding RNAs: analysis of their gene structure, evolution, and expression. Genome Res (2012) 22(9):1775-89. doi:10.1101/gr.132159.111

2. Taft RJ, Pheasant M, Mattick JS. The relationship between non-protein-coding DNA and eukaryotic complexity. Bioessays (2007) 29(3):288-99. doi:10.1002/ bies. 20544

3. Hoagland MB, Keller EB, Zamecnik PC. Enzymatic carboxyl activation of amino acids. J Biol Chem (1956) 218(1):345-58.

4. Pasquinelli AE, Reinhart BJ, Slack F, Martindale MQ, Kuroda MI, Maller B, et al. Conservation of the sequence and temporal expression of let-7 heterochronic regulatory RNA. Nature (2000) 408(6808):86-9. doi:10.1038/35040556

5. Baumjohann D, Ansel KM. MicroRNA-mediated regulation of T helper cell differentiation and plasticity. Nat Rev Immunol (2013) 13(9):666-78. doi:10.1038/nri3494

6. Bronevetsky Y, Ansel KM. Regulation of miRNA biogenesis and turnover in the immune system. Immunol Rev (2013) 253(1):304-16. doi:10.1111/imr.12059

7. Monticelli S. MicroRNAs in T helper cell differentiation and plasticity. Semin Immunol (2013) 25(4):291-8. doi:10.1016/j.smim.2013.10.015

8. Bratkovič T, Rogelj B. The many faces of small nucleolar RNAs. Biochim Biophys Acta (2014) 1839(6):438-43. doi:10.1016/j.bbagrm.2014.04.009

9. Dieci G, Preti M, Montanini B. Eukaryotic snoRNAs: a paradigm for gene expression flexibility. Genomics (2009) 94(2):83-8. doi:10.1016/j.ygeno.2009. 05.002

10. Lui L, Lowe T. Small nucleolar RNAs and RNA-guided post-transcriptional modification. Essays Biochem (2013) 54:53-77. doi:10.1042/bse0540053

11. Valadkhan S, Gunawardane LS. Role of small nuclear RNAs in eukaryotic gene expression. Essays Biochem (2013) 54:79-90. doi:10.1042/bse0540079

12. Bamezai S, Rawat VPS, Buske C. Concise review: the Piwi-piRNA axis: pivotal beyond transposon silencing. Stem Cells (2012) 30(12):2603-11. doi:10.1002/ stem. 1237

13. Ku H-Y, Lin H. PIWI proteins and their interactors in piRNA biogenesis, germline development and gene expression. Natl Sci Rev (2014) 1(2):205-18. doi:10.1093/nsr/nwu014

14. Luteijn MJ, Ketting RF. PIWI-interacting RNAs: from generation to transgenerational epigenetics. Nat Rev Genet (2013) 14(8):523-34. doi:10.1038/nrg3495

15. Kapranov P, Cheng J, Dike S, Nix DA, Duttagupta R, Willingham AT, et al. RNA maps reveal new RNA classes and a possible function for pervasive transcription. Science (2007) 316(5830):1484-8. doi:10.1126/science.1138341

16. Taft RJ, Kaplan CD, Simons C, Mattick JS. Evolution, biogenesis and function of promoter-associated RNAs. Cell Cycle (2009) 8(15):2332-8. doi:10.4161/cc. 8.15.9154 
17. Carthew RW, Sontheimer EJ. Origins and mechanisms of miRNAs and siRNAs. Cell (2009) 136(4):642-55. doi:10.1016/j.cell.2009.01.035

18. Svoboda P. Renaissance of mammalian endogenous RNAi. FEBS Lett (2014) 588(15):2550-6. doi:10.1016/j.febslet.2014.05.030

19. Taft RJ, Glazov EA, Cloonan N, Simons C, Stephen S, Faulkner GJ, et al. Tiny RNAs associated with transcription start sites in animals. Nat Genet (2009) 41(5):572-8. doi:10.1038/ng.312

20. Taft RJ, Simons C, Nahkuri S, Oey H, Korbie DJ, Mercer TR, et al. Nuclearlocalized tiny RNAs are associated with transcription initiation and splice sites in metazoans. Nat Struct Mol Biol (2010) 17(8):1030-4. doi:10.1038/nsmb. 1841

21. Djebali S, Davis CA, Merkel A, Dobin A, Lassmann T, Mortazavi AM, et al. Landscape of transcription in human cells. Nature (2012) 489(7414):101-8. doi:10.1038/nature11233

22. Faghihi MA, Wahlestedt C. Regulatory roles of natural antisense transcripts. Nat Rev Mol Cell Biol (2009) 10(9):637-43. doi:10.1038/nrm2738

23. Kurokawa R. Promoter-associated long noncoding RNAs repress transcription through a RNA binding protein TLS. Adv Exp Med Biol (2011) 722:196-208. doi:10.1007/978-1-4614-0332-6_12

24. Zaphiropoulos PG. A promoter-associated RNA downregulates the oncogenic GLI1 transcription factor in rhabdomyosarcoma cells. RNA Dis (2014) 1(1):e254. doi:10.14800/rd.254

25. Preker P, Nielsen J, Kammler S, Lykke-Andersen S, Christensen MS, Mapendano CK, et al. RNA exosome depletion reveals transcription upstream of active human promoters. Science (2008) 322(5909):1851-4. doi:10.1126/science. 1164096

26. Imamura T, Yamamoto S, Ohgane J, Hattori N, Tanaka S, Shiota K. Non-coding RNA directed DNA demethylation of Sphk1 CpG island. Biochem Biophys Res Commun (2004) 322(2):593-600. doi:10.1016/j.bbrc.2004.07.159

27. Preker P, Almvig K, Christensen MS, Valen E, Mapendano CK, Sandelin A, et al. PROMoter uPstream Transcripts share characteristics with mRNAs and are produced upstream of all three major types of mammalian promoters. Nucleic Acids Res (2011) 39(16):7179-93. doi:10.1093/nar/gkr370

28. Peng JC, Shen J, Ran ZH. Transcribed ultraconserved region in human cancers. RNA Biol (2013) 10(12):1771-7. doi:10.4161/rna.26995

29. Louro R, Smirnova AS, Verjovski-Almeida S. Long intronic noncoding RNA transcription: expression noise or expression choice? Genomics (2009) 93(4):291-8. doi:10.1016/j.ygeno.2008.11.009

30. Lam MT, Li W, Rosenfeld MG, Glass CK. Enhancer RNAs and regulated transcriptional programs. Trends Biochem Sci (2014) 39(4):170-82. doi:10.1016/j. tibs.2014.02.007

31. Koch F, Fenouil R, Gut M, Cauchy P, Albert TK, Zacarias-Cabeza J, et al. Transcription initiation platforms and GTF recruitment at tissue-specific enhancers and promoters. Nat Struct Mol Biol (2011) 18(8):956-63. doi:10.1038/nsmb. 2085

32. Natoli G, Andrau JC. Noncoding transcription at enhancers: general principles and functional models. Annu Rev Genet (2012) 46:1-19. doi:10.1146/annurevgenet-110711-155459

33. Rinn JL, Chang HY. Genome regulation by long noncoding RNAs. Annu Rev Biochem (2012) 81:145-66. doi:10.1146/annurev-biochem-051410-92902

34. Merry C, Niland C, Khalil A. Diverse functions and mechanisms of mammalian long noncoding RNAs. In: Carmichael GG, editor. Regulatory NonCoding RNAs: Methods in Molecular Biology. Vol. 1206. New York, NY: Springer (2015). p. 1-14.

35. Mercer TR, Wilhelm D, Dinger ME, Soldà G, Korbie DJ, Glazov EA, et al. Expression of distinct RNAs from 3' untranslated regions. Nucleic Acids Res (2011) 39(6):2393-403. doi:10.1093/nar/gkq1158

36. Lasda E, Parker R. Circular RNAs: diversity of form and function. RNA (2014) 20(12):1829-42. doi:10.1261/rna.047126.114

37. Pang KC, Dinger ME, Mercer TR, Malquori L, Grimmond SM, Chen W, et al. Genome-wide identification of long noncoding RNAs in CD8+ T cells. J Immunol (2009) 182(12):7738-48. doi:10.4049/jimmunol.0900603

38. Pagani M, Rossetti G, Panzeri I, de Candia P, Bonnal RJ, Rossi RL, et al. Role of microRNAs and long-non-coding RNAs in CD4(+) T-cell differentiation. Immunol Rev (2013) 253(1):82-96. doi:10.1111/imr.12055

39. Guttman M, Amit I, Garber M, French C, Lin MF, Feldser D, et al. Chromatin signature reveals over a thousand highly conserved large non-coding RNAs in mammals. Nature (2009) 458(7235):223-7. doi:10.1038/nature07672
40. Dieci G, Conti A, Pagano A, Carnevali D. Identification of RNA polymerase IIItranscribed genes in eukaryotic genomes. Biochim Biophys Acta (2013) 1829(34):296-305. doi:10.1016/j.bbagrm.2012.09.010

41. Lin R, Maeda S, Liu C, Karin M, Edgington TS. A large noncoding RNA is a marker for murine hepatocellular carcinomas and a spectrum of human carcinomas. Oncogene (2007) 26(6):851-8. doi:10.1038/sj.onc.1209846

42. Galindo MI, Pueyo JI, Fouix S, Bishop SA, Couso JP. Peptides encoded by short ORFs control development and define a new eukaryotic gene family. PLoS Biol (2007) 5(5):e106. doi:10.1371/journal.pbio.0050106

43. Lanz RB, McKenna NJ, Onate SA, Albrecht U, Wong J, Tsai SY, et al. A steroid receptor coactivator, SRA, functions as an RNA and is present in an SRC-1 complex. Cell (1999) 97(1):17-27. doi:10.1016/S0092-8674(00)80711-4

44. Ingolia NT, Brar GA, Stern-Ginossar N, Harris MS, Talhouarne GJ, Jackson $\mathrm{SE}$, et al. Ribosome profiling reveals pervasive translation outside of annotated protein-coding genes. Cell Rep (2014) 8(5):1365-79. doi:10.1016/j.celrep.2014. 07.045

45. Banfai B, Jia H, Khatun J, Wood E, Risk B, Gundling WE Jr, et al. Long noncoding RNAs are rarely translated in two human cell lines. Genome Res (2012) 22(9):1646-57. doi:10.1101/gr.134767.111

46. Lee S, Liu B, Lee S, Huang SX, Shen B, Qian SB. Global mapping of translation initiation sites in mammalian cells at single-nucleotide resolution. Proc Natl Acad Sci U S A (2012) 109(37):E2424-32. doi:10.1073/pnas.1207846109

47. Slavoff SA, Mitchell AJ, Schwaid AG, Cabili MN, Ma J, Levin JZ, et al. Peptidomic discovery of short open reading frame-encoded peptides in human cells. Nat Chem Biol (2013) 9(1):59-64. doi:10.1038/nchembio.1120

48. Andrews SJ, Rothnagel JA. Emerging evidence for functional peptides encoded by short open reading frames. Nat Rev Genet (2014) 15(3):193-204. doi:10. 1038/nrg3520

49. Ulveling D, Francastel C, Hube F. When one is better than two: RNA with dual functions. Biochimie (2011) 93(4):633-44. doi:10.1016/j.biochi.2010.11.004

50. Poliseno L, Salmena L, Zhang J, Carver B, Haveman WJ, Pandolfi PP. A codingindependent function of gene and pseudogene mRNAs regulates tumour biology. Nature (2010) 465(7301):1033-8. doi:10.1038/nature09144

51. Duret L, Chureau C, Samain S, Weissenbach J, Avner P. The Xist RNA gene evolved in eutherians by pseudogenization of a protein-coding gene. Science (2006) 312(5780):1653-5. doi:10.1126/science.1126316

52. Elisaphenko EA, Kolesnikov NN, Shevchenko AI, Rogozin IB, Nesterova $\mathrm{TB}$, Brockdorff $\mathrm{N}$, et al. A dual origin of the Xist gene from a proteincoding gene and a set of transposable elements. PLoS One (2008) 3(6):e2521. doi:10.1371/journal.pone.0002521

53. Horvath JE, Sheedy CB, Merrett SL, Diallo AB, Swofford DL, Program NCS, et al. Comparative analysis of the primate $\mathrm{X}$-inactivation center region and reconstruction of the ancestral primate XIST locus. Genome Res (2011) 21(6):850-62. doi:10.1101/gr.111849.110

54. Romito A, Rougeulle C. Origin and evolution of the long non-coding genes in the X-inactivation center. Biochimie (2011) 93(11):1935-42. doi:10.1016/j. biochi.2011.07.009

55. Bussotti G, Notredame C, Enright A. Detecting and comparing non-coding RNAs in the high-throughput era. Int J Mol Sci (2013) 14(8):15423-58. doi:10.3390/ijms140815423

56. Nigro JM, Cho KR, Fearon ER, Kern SE, Ruppert JM, Oliner JD, et al. Scrambled exons. Cell (1991) 64(3):607-13. doi:10.1016/0092-8674(91)90244-S

57. Beltran M, Puig I, Peña C, García JM, Álvarez AB, Peña R, et al. A natural antisense transcript regulates Zeb2/Sip1 gene expression during Snail1induced epithelial-mesenchymal transition. Genes Dev (2008) 22(6):756-69. doi:10.1101/gad.455708

58. Martick M, Horan LH, Noller HF, Scott WG. A discontinuous hammerhead ribozyme embedded in a mammalian messenger RNA. Nature (2008) 454(7206):899-902. doi:10.1038/nature07117

59. Mercer TR, Gerhardt DJ, Dinger ME, Crawford J, Trapnell C, Jeddeloh JA, et al. Targeted RNA sequencing reveals the deep complexity of the human transcriptome. Nat Biotech (2012) 30(1):99-104. doi:10.1038/nbt.2024

60. Katayama S, Tomaru Y, Kasukawa T, Waki K, Nakanishi M, Nakamura M, et al. Antisense transcription in the mammalian transcriptome. Science (2005) 309(5740):1564-6. doi:10.1126/science.1112009

61. Li Z, Rana TM. Decoding the noncoding: prospective of lncRNA-mediated innate immune regulation. RNA Biol (2014) 11(8):979-85. doi:10.4161/rna. 29937 
62. Imamura K, Akimitsu N. Long non-coding RNAs involved in immune responses. Front Immunol (2014) 5:573. doi:10.3389/fimmu.2014.00573

63. Ranzani VRG, Panzeri I, Arrigoni A, Bonnal R, Curti S, Gruarin P, et al. LincRNA landscape in human lymphocytes highlights regulation of $\mathrm{T}$ cell differentiation by linc-MAF-4. Nat Immunol (2015) 16(3):318-25. doi:10.1038/ni.3093

64. Kapusta A, Kronenberg Z, Lynch VJ, Zhuo X, Ramsay L, Bourque G, et al. Transposable elements are major contributors to the origin, diversification, and regulation of vertebrate long noncoding RNAs. PLoS Genet (2013) 9(4):e1003470. doi:10.1371/journal.pgen.1003470

65. Kelley D, Rinn J. Transposable elements reveal a stem cell-specific class of long noncoding RNAs. Genome Biol (2012) 13(11):R107. doi:10.1186/gb-2012-1311-r107

66. Lin N, Chang KY, Li Z, Gates K, Rana ZA, Dang J, et al. An evolutionarily conserved long noncoding RNA TUNA controls pluripotency and neural lineage commitment. Mol Cell (2014) 53(6):1005-19. doi:10.1016/j.molcel.2014. 01.021

67. Klattenhoff CA, Scheuermann JC, Surface LE, Bradley RK, Fields PA, Steinhauser ML, et al. Braveheart, a long noncoding RNA required for cardiovascular lineage commitment. Cell (2013) 152(3):570-83. doi:10.1016/j.cell.2013. 01.003

68. Wang KC, Yang YW, Liu B, Sanyal A, Corces-Zimmerman R, Chen Y, et al. A long noncoding RNA maintains active chromatin to coordinate homeotic gene expression. Nature (2011) 472(7341):120-4. doi:10.1038/nature09819

69. Keniry A, Oxley D, Monnier P, Kyba M, Dandolo L, Smits G, et al. The H19 lincRNA is a developmental reservoir of miR-675 that suppresses growth and Igf1r. Nat Cell Biol (2012) 14(7):659-65. doi:10.1038/ncb2521

70. Venkatraman A, He XC, Thorvaldsen JL, Sugimura R, Perry JM, Tao F, et al. Maternal imprinting at the H19-Igf2 locus maintains adult haematopoietic stem cell quiescence. Nature (2013) 500(7462):345-9. doi:10.1038/ nature 12303

71. Mourtada-Maarabouni M, Hedge VL, Kirkham L, Farzaneh F, Williams GT. Growth arrest in human T-cells is controlled by the non-coding RNA growth-arrest-specific transcript 5 (GAS5). J Cell Sci (2008) 121(7):939-46. doi:10.1242/jcs.024646

72. Pickard MR, Mourtada-Maarabouni M, Williams GT. Long non-coding RNA GAS5 regulates apoptosis in prostate cancer cell lines. Biochim Biophys Acta (2013) 1832(10):1613-23. doi:10.1016/j.bbadis.2013.05.005

73. Rossi MN, Antonangeli F. LncRNAs: new players in apoptosis control. Int J Cell Biol (2014) 2014:7. doi:10.1155/2014/473857

74. Yin D, He X, Zhang E, Kong R, De W, Zhang Z. Long noncoding RNA GAS5 affects cell proliferation and predicts a poor prognosis in patients with colorectal cancer. Med Oncol (2014) 31(11):253. doi:10.1007/s12032-014-0253-8

75. Cesana M, Cacchiarelli D, Legnini I, Santini T, Sthandier O, Chinappi M, et al. A long noncoding RNA controls muscle differentiation by functioning as a competing endogenous RNA. Cell (2011) 147(2):358-69. doi:10.1016/j.cell.2011. 09.028

76. Fatica A, Bozzoni I. Long non-coding RNAs: new players in cell differentiation and development. Nat Rev Genet (2014) 15(1):7-21. doi:10.1038/nrg3606

77. Hu W, Alvarez-Dominguez JR, Lodish HF. Regulation of mammalian cell differentiation by long non-coding RNAs. EMBO Rep (2012) 13(11):971-83. doi:10.1038/embor.2012.145

78. Lee Jeannie T, Bartolomei Marisa S. X-inactivation, imprinting, and long noncoding RNAs in health and disease. Cell (2013) 152(6):1308-23. doi:10.1016/ j.cell.2013.02.016

79. Mitsuya K, Meguro M, Lee MP, Katoh M, Schulz TC, Kugoh H, et al. LIT1, an imprinted antisense RNA in the human KvLQT1 locus identified by screening for differentially expressed transcripts using monochromosomal hybrids. Hum Mol Genet (1999) 8(7):1209-17. doi:10.1093/hmg/8.7.1209

80. Zhang H, Zeitz MJ, Wang H, Niu B, Ge S, Li W, et al. Long noncoding RNAmediated intrachromosomal interactions promote imprinting at the Kcnq1 locus. J Cell Biol (2014) 204(1):61-75. doi:10.1083/jcb.201304152

81. Gendrel AV, Heard E. Noncoding RNAs and epigenetic mechanisms during X-chromosome inactivation. Annu Rev Cell Dev Biol (2014) 30:561-80. doi:10.1146/annurev-cellbio-101512-122415

82. Khalil AM, Guttman M, Huarte M, Garber M, Raj A, Rivea Morales D, et al. Many human large intergenic noncoding RNAs associate with chromatinmodifying complexes and affect gene expression. Proc Natl Acad Sci U S A (2009) 106(28):11667-72. doi:10.1073/pnas.0904715106
83. Salmena L, Poliseno L, Tay Y, Kats L, Pandolfi Pier P. A ceRNA hypothesis: the Rosetta stone of a hidden RNA language? Cell (2011) 146(3):353-8. doi:10.1016/j.cell.2011.07.014

84. Willingham AT, Orth AP, Batalov S, Peters EC, Wen BG, Aza-Blanc P, et al. A strategy for probing the function of noncoding RNAs finds a repressor of NFAT. Science (2005) 309(5740):1570-3. doi:10.1126/science.1115901

85. Carrieri C, Cimatti L, Biagioli M, Beugnet A, Zucchelli S, Fedele S, et al. Long non-coding antisense RNA controls Uchll translation through an embedded SINEB2 repeat. Nature (2012) 491(7424):454-7. doi:10.1038/nature11508

86. Tripathi V, Ellis JD, Shen Z, Song DY, Pan Q, Watt AT, et al. The nuclearretained noncoding RNA MALAT1 regulates alternative splicing by modulating SR splicing factor phosphorylation. Mol Cell (2010) 39(6):925-38. doi:10.1016/j.molcel.2010.08.011

87. Conrad NK. The emerging role of triple helices in RNA biology. Wiley Interdiscip Rev RNA (2014) 5(1):15-29. doi:10.1002/wrna.1194

88. Cruz JA, Westhof E. The dynamic landscapes of RNA architecture. Cell (2009) 136(4):604-9. doi:10.1016/j.cell.2009.02.003

89. Lescoute A, Westhof E. Topology of three-way junctions in folded RNAs. RNA (2006) 12(1):83-93. doi:10.1261/rna.2208106

90. Jia G, Fu Y, Zhao X, Dai Q, Zheng G, Yang Y, et al. N6-Methyladenosine in nuclear RNA is a major substrate of the obesity-associated FTO. Nat Chem Biol (2011) 7(12):885-7. doi:10.1038/nchembio.687

91. Yang Y, Zhou X, Jin Y. ADAR-mediated RNA editing in non-coding RNA sequences. Sci China Life Sci (2013) 56(10):944-52. doi:10.1007/s11427-0134546-5

92. Squires JE, Patel HR, Nousch M, Sibbritt T, Humphreys DT, Parker BJ, et al. Widespread occurrence of 5-methylcytosine in human coding and non-coding RNA. Nucleic Acids Res (2012) 40(11):5023-33. doi:10.1093/nar/gks144

93. Chi SW, Hannon GJ, Darnell RB. An alternative mode of microRNA target recognition. Nat Struct Mol Biol (2012) 19(3):321-7. doi:10.1038/nsmb.2230

94. Mariner PD, Walters RD, Espinoza CA, Drullinger LF, Wagner SD, Kugel JF, et al. Human Alu RNA is a modular transacting repressor of mRNA transcription during heat shock. Mol Cell (2008) 29(4):499-509. doi:10.1016/j.molcel. 2007.12.013

95. Kutter C, Watt S, Stefflova K, Wilson MD, Goncalves A, Ponting CP, et al. Rapid turnover of long noncoding RNAs and the evolution of gene expression. PLoS Genet (2012) 8(7):e1002841. doi:10.1371/journal.pgen.1002841

96. Ponjavic J, Ponting CP, Lunter G. Functionality or transcriptional noise? Evidence for selection within long noncoding RNAs. Genome Res (2007) 17(5):556-65. doi:10.1101/gr.6036807

97. Marques AC, Ponting CP. Intergenic lncRNAs and the evolution of gene expression. Curr Opin Genet Dev (2014) 27(0):48-53. doi:10.1016/j.gde.2014.03.009

98. Engreitz Jesse M, Sirokman K, McDonel P, Shishkin AA, Surka C, Russell $\mathrm{P}$, et al. RNA-RNA interactions enable specific targeting of noncoding RNAs to nascent pre-mRNAs and chromatin sites. Cell (2014) 159(1):188-99. doi:10.1016/j.cell.2014.08.018

99. Chu C, Qu K, Zhong FL, Artandi SE, Chang HY. Genomic maps of long noncoding RNA occupancy reveal principles of RNA-chromatin interactions. $\mathrm{Mol}$ Cell (2011) 44(4):667-78. doi:10.1016/j.molcel.2011.08.027

100. Schmitz KM, Mayer C, Postepska A, Grummt I. Interaction of noncoding RNA with the rDNA promoter mediates recruitment of DNMT3b and silencing of rRNA genes. Genes Dev (2010) 24(20):2264-9. doi:10.1101/gad.590910

101. Clemson CM, Hutchinson JN, Sara SA, Ensminger AW, Fox AH, Chess A, et al. An architectural role for a nuclear noncoding RNA: NEAT1 RNA is essential for the structure of paraspeckles. Mol Cell (2009) 33(6):717-26. doi:10.1016/j.molcel.2009.01.026

102. Imamura K, Imamachi N, Akizuki G, Kumakura M, Kawaguchi A, Nagata K, et al. Long noncoding RNA NEAT1-dependent SFPQ relocation from promoter region to paraspeckle mediates IL8 expression upon immune stimuli. Mol Cell (2014) 53(3):393-406. doi:10.1016/j.molcel.2014.01.009

103. Abarrategui I, Krangel MS. Noncoding transcription controls downstream promoters to regulate T-cell receptor alpha recombination. EMBO J (2007) 26(20):4380-90. doi:10.1038/sj.emboj.7601866

104. Bolland DJ, Wood AL, Johnston CM, Bunting SF, Morgan G, Chakalova L, et al. Antisense intergenic transcription in $\mathrm{V}(\mathrm{D}) \mathrm{J}$ recombination. Nat Immunol (2004) 5(6):630-7. doi:10.1038/ni1068

105. Verma-Gaur J, Torkamani A, Schaffer L, Head SR, Schork NJ, Feeney AJ. Noncoding transcription within the Igh distal $\mathrm{V}(\mathrm{H})$ region at PAIR elements affects 
the 3D structure of the Igh locus in pro-B cells. Proc Natl Acad Sci U S A (2012) 109(42):17004-9. doi:10.1073/pnas.1208398109

106. Kino T, Hurt DE, Ichijo T, Nader N, Chrousos GP. Noncoding RNA gas5 is a growth arrest- and starvation-associated repressor of the glucocorticoid receptor. Sci Signal (2010) 3(107):ra8. doi:10.1126/scisignal.2000568

107. Williams GT, Mourtada-Maarabouni M, Farzaneh F. A critical role for noncoding RNA GAS5 in growth arrest and rapamycin inhibition in human Tlymphocytes. Biochem Soc Trans (2011) 39(2):482-6. doi:10.1042/BST0390482

108. Bird A. Perceptions of epigenetics. Nature (2007) 447(7143):396-8. doi:10. 1038/nature05913

109. Goldberg AD, Allis CD, Bernstein E. Epigenetics: a landscape takes shape. Cell (2007) 128(4):635-8. doi:10.1016/j.cell.2007.02.006

110. Costa FF. Non-coding RNAs, epigenetics and complexity. Gene (2008) 410(1):9-17. doi:10.1016/j.gene.2007.12.008

111. Ansel KM, Lee DU, Rao A. An epigenetic view of helper T cell differentiation. Nat Immunol (2003) 4(7):616-23. doi:10.1038/ni0703-616

112. Tripathi SK, Lahesmaa R. Transcriptional and epigenetic regulation of Thelper lineage specification. Immunol Rev (2014) 261(1):62-83. doi:10.1111/ imr. 12204

113. Ansel KM, Djuretic I, Tanasa B, Rao A. Regulation of Th2 differentiation and Il4 locus accessibility. Annu Rev Immunol (2006) 24:607-56. doi:10.1146/annurev. immunol.23.021704.115821

114. Balasubramani A, Mukasa R, Hatton RD, Weaver CT. Regulation of the Ifng locus in the context of T-lineage specification and plasticity. Immunol Rev (2010) 238(1):216-32. doi:10.1111/j.1600-065X.2010.00961.x

115. Chang S, Aune TM. Dynamic changes in histone-methylation 'marks' across the locus encoding interferon-gamma during the differentiation of $\mathrm{T}$ helper type 2 cells. Nat Immunol (2007) 8(7):723-31. doi:10.1038/ni1473

116. Ballas ZK. The use of 5-azacytidine to establish constitutive interleukin 2producing clones of the EL4 thymoma. J Immunol (1984) 133(1):7-9.

117. Young HA, Ghosh P, Ye J, Lederer J, Lichtman A, Gerard JR, et al. Differentiation of the $\mathrm{T}$ helper phenotypes by analysis of the methylation state of the IFN-gamma gene. J Immunol (1994) 153(8):3603-10.

118. Bird JJ, Brown DR, Mullen AC, Moskowitz NH, Mahowald MA, Sider JR, et al. Helper T cell differentiation is controlled by the cell cycle. Immunity (1998) 9(2):229-37. doi:10.1016/S1074-7613(00)80605-6

119. Morinobu A, Kanno Y, O'Shea JJ. Discrete roles for histone acetylation in human $\mathrm{T}$ helper 1 cell-specific gene expression. J Biol Chem (2004) 279(39):40640-6. doi:10.1074/jbc.M407576200

120. Valapour M, Guo J, Schroeder JT, Keen J, Cianferoni A, Casolaro V, et al. Histone deacetylation inhibits IL4 gene expression in T cells. J Allergy Clin Immunol (2002) 109(2):238-45. doi:10.1067/mai.2002.121145

121. Hutchins AS, Mullen AC, Lee HW, Sykes KJ, High FA, Hendrich BD, et al. Gene silencing quantitatively controls the function of a developmental transactivator. Mol Cell (2002) 10(1):81-91. doi:10.1016/S1097-2765(02)00564-6

122. Lee PP, Fitzpatrick DR, Beard C, Jessup HK, Lehar S, Makar KW, et al. A critical role for Dnmtl and DNA methylation in T cell development, function, and survival. Immunity (2001) 15(5):763-74. doi:10.1016/S1074-7613(01)00227-8

123. Makar KW, Perez-Melgosa M, Shnyreva M, Weaver WM, Fitzpatrick DR, Wilson CB. Active recruitment of DNA methyltransferases regulates interleukin 4 in thymocytes and T cells. Nat Immunol (2003) 4(12):1183-90. doi:10.1038/ni1004

124. Yamashita M, Hirahara K, Shinnakasu R, Hosokawa H, Norikane S, Kimura MY, et al. Crucial role of MLL for the maintenance of memory T helper type 2 cell responses. Immunity (2006) 24(5):611-22. doi:10.1016/j.immuni.2006.03.017

125. Onodera A, Yamashita M, Endo Y, Kuwahara M, Tofukuji S, Hosokawa H, et al. STAT6-mediated displacement of polycomb by trithorax complex establishes long-term maintenance of GATA3 expression in T helper type 2 cells. J Exp Med (2010) 207(11):2493-506. doi:10.1084/jem.20100760

126. Kimura M, Koseki Y, Yamashita M, Watanabe N, Shimizu C, Katsumoto T, et al. Regulation of Th2 cell differentiation by mel-18, a mammalian polycomb group gene. Immunity (2001) 15(2):275-87. doi:10.1016/S1074-7613(01)00182-0

127. Yamashita M, Kuwahara M, Suzuki A, Hirahara K, Shinnaksu R, Hosokawa H, et al. Bmil regulates memory CD4 T cell survival via repression of the Noxa gene. J Exp Med (2008) 205(5):1109-20. doi:10.1084/jem.20072000

128. Koyanagi M, Baguet A, Martens J, Margueron R, Jenuwein T, Bix M. EZH2 and histone 3 trimethyl lysine 27 associated with Il4 and Il13 gene silencing in Th1 cells. J Biol Chem (2005) 280(36):31470-7. doi:10.1074/jbc.M504766200
129. Su IH, Dobenecker MW, Dickinson E, Oser M, Basavaraj A, Marqueron R, et al. Polycomb group protein ezh2 controls actin polymerization and cell signaling. Cell (2005) 121(3):425-36. doi:10.1016/j.cell.2005.02.029

130. Wei G, Wei L, Zhu J, Zang C, Hu-Li J, Yao Z, et al. Global mapping of $\mathrm{H} 3 \mathrm{~K} 4 \mathrm{me} 3$ and $\mathrm{H} 3 \mathrm{~K} 27 \mathrm{me} 3$ reveals specificity and plasticity in lineage fate determination of differentiating CD4+ T cells. Immunity (2009) 30(1):155-67. doi:10.1016/j.immuni.2008.12.009

131. Hirahara K, Vahedi G, Ghoreschi K, Yang XP, Nakayamada S, Kanno Y, et al. Helper T-cell differentiation and plasticity: insights from epigenetics. Immunology (2011) 134(3):235-45. doi:10.1111/j.1365-2567.2011.03483.x

132. Bernstein BE, Meissner A, Lander ES. The mammalian epigenome. Cell (2007) 128(4):669-81. doi:10.1016/j.cell.2007.01.033

133. Grogan JL, Mohrs M, Harmon B, Lacy DA, Sedat JW, Locksley RM. Early transcription and silencing of cytokine genes underlie polarization of $\mathrm{T}$ helper cell subsets. Immunity (2001) 14(3):205-15. doi:10.1016/S1074-7613(01)00103-0

134. Mullen AC, High FA, Hutchins AS, Lee HW, Villarino AV, Livingston DM, et al. Role of T-bet in commitment of TH1 cells before IL-12-dependent selection. Science (2001) 292(5523):1907-10. doi:10.1126/science.1059835

135. Panzer M, Sitte S, Wirth S, Drexler I, Sparwasser T, Voehringer D. Rapid in vivo conversion of effector $\mathrm{T}$ cells into Th2 cells during helminth infection. J Immunol (2012) 188(2):615-23. doi:10.4049/jimmunol.1101164

136. Peine M, Rausch S, Helmstetter C, Fröhlich A, Hegazy AN, Kühl AA, et al. Stable T-bet(+)GATA-3(+) Th1/Th2 hybrid cells arise in vivo, can develop directly from naive precursors, and limit immunopathologic inflammation. PLoS Biol (2013) 11(8):e1001633. doi:10.1371/journal.pbio.1001633

137. Zhao J, Ohsumi TK, Kung JT, Ogawa Y, Grau DJ, Sarma K, et al. Genomewide identification of polycomb-associated RNAs by RIP-seq. Mol Cell (2010) 40(6):939-53. doi:10.1016/j.molcel.2010.12.011

138. Tsai MC, Manor O, Wan Y, Mosammaparast N, Wang JK, Lan F, et al. Long noncoding RNA as modular scaffold of histone modification complexes. Science (2010) 329(5992):689-93. doi:10.1126/science.1192002

139. Guttman M, Donaghey J, Carey BW, Garber M, Grenier JK, Munson G, et al. lincRNAs act in the circuitry controlling pluripotency and differentiation. Nature (2011) 477(7364):295-300. doi:10.1038/nature 10398

140. Schuettengruber B, Ganapathi M, Leblanc B, Portoso M, Jaschek R, Tolhuis $\mathrm{B}$, et al. Functional anatomy of polycomb and trithorax chromatin landscapes in Drosophila embryos. PLoS Biol (2009) 7(1):e1000013. doi:10.1371/journal. pbio. 1000013

141. Kassis JA, Brown JL. Polycomb group response elements in Drosophila and vertebrates. Adv Genet (2013) 81:83-118. doi:10.1016/B978-0-12-407677-8. 00003-8

142. Bernstein E, Allis CD. RNA meets chromatin. Genes Dev (2005) 19(14):1635-55. doi:10.1101/gad.1324305

143. Jeffery L, Nakielny S. Components of the DNA methylation system of chromatin control are RNA-binding proteins. J Biol Chem (2004) 279(47):49479-87. doi:10.1074/jbc.M409070200

144. Hiragami-Hamada K, Fischle W. RNAs - physical and functional modulators of chromatin reader proteins. Biochim Biophys Acta (2014) 1839(8):737-42. doi:10.1016/j.bbagrm.2014.03.015

145. Zhao J, Sun BK, Erwin JA, Song J-J, Lee JT. Polycomb proteins targeted by a short repeat RNA to the mouse X chromosome. Science (2008) 322(5902):750-6. doi:10.1126/science. 1163045

146. Pandey RR, Mondal T, Mohammad F, Enroth S, Redrup L, Komorowski J, et al. Kcnqlotl antisense noncoding RNA mediates lineage-specific transcriptional silencing through chromatin-level regulation. Mol Cell (2008) 32(2):232-46. doi:10.1016/j.molcel.2008.08.022

147. Yang L, Lin C, Liu W, Zhang J, Ohgi KA, Grinstein JD, et al. ncRNA- and Pc2 methylation-dependent gene relocation between nuclear structures mediates gene activation programs. Cell (2011) 147(4):773-88. doi:10.1016/j.cell.2011. 08.054

148. Chalei V, Sansom SN, Kong L, Lee S, Montiel JF, Vance KW, et al. The long non-coding RNA Dali is an epigenetic regulator of neural differentiation. Elife (2014) 3:e04530. doi:10.7554/eLife.04530

149. Steffen PA, Ringrose L. What are memories made of? How polycomb and trithorax proteins mediate epigenetic memory. Nat Rev Mol Cell Biol (2014) 15(5):340-56. doi:10.1038/nrm3789

150. Arab K, Park YJ, Lindroth AM, Schafer A, Oakes C, Weichenhan D, et al. Long noncoding RNA TARID directs demethylation and activation of the 
tumor suppressor TCF21 via GADD45A. Mol Cell (2014) 55(4):604-14. doi:10.1016/j.molcel.2014.06.031

151. Iyer LM, Abhiman S, Aravind L. Natural history of eukaryotic DNA methylation systems. Prog Mol Biol Transl Sci (2011) 101:25-104. doi:10.1016/B978-012-387685-0.00002-0

152. Ponnaluri VK, Maciejewski JP, Mukherji M. A mechanistic overview of TETmediated 5-methylcytosine oxidation. Biochem Biophys Res Commun (2013) 436(2):115-20. doi:10.1016/j.bbrc.2013.05.077

153. Lee JT. Epigenetic regulation by long noncoding RNAs. Science (2012) 338(6113):1435-9. doi:10.1126/science.1231776

154. Rinn JL, Kertesz M, Wang JK, Squazzo SL, Xu X, Brugmann SA, et al. Functional demarcation of active and silent chromatin domains in human HOX loci by noncoding RNAs. Cell (2007) 129(7):1311-23. doi:10.1016/j.cell.2007.05.022

155. Cremer T, Cremer C. Chromosome territories, nuclear architecture and gene regulation in mammalian cells. Nat Rev Genet (2001) 2(4):292-301. doi:10.1038/35066075

156. Sleeman JE, Trinkle-Mulcahy L. Nuclear bodies: new insights into assembly/dynamics and disease relevance. Curr Opin Cell Biol (2014) 28(0):76-83. doi:10.1016/j.ceb.2014.03.004

157. Reddy KL, Zullo JM, Bertolino E, Singh H. Transcriptional repression mediated by repositioning of genes to the nuclear lamina. Nature (2008) 452(7184):243-7. doi:10.1038/nature06727

158. Kumaran RI, Thakar R, Spector DL. Chromatin dynamics and gene positioning. Cell (2008) 132(6):929-34. doi:10.1016/j.cell.2008.03.004

159. Kosak ST, Skok JA, Medina KL, Riblet R, Le Beau MM, Fisher AG, et al. Subnuclear compartmentalization of immunoglobulin loci during lymphocyte development. Science (2002) 296(5565):158-62. doi:10.1126/science.1068768

160. Yao H, Brick K, Evrard Y, Xiao T, Camerini-Otero RD, Felsenfeld G. Mediation of CTCF transcriptional insulation by DEAD-box RNA-binding protein p68 and steroid receptor RNA activator SRA. Genes Dev (2010) 24(22):2543-55. doi:10.1101/gad.1967810

161. Xiang J-F, Yin Q-F, Chen T, Zhang Y, Zhang X-O, Wu Z, et al. Human colorectal cancer-specific CCAT1-L lncRNA regulates long-range chromatin interactions at the MYC locus. Cell Res (2014) 24(5):513-31. doi:10.1038/cr.2014.35

162. Hacisuleyman E, Goff LA, Trapnell C, Williams A, Henao-Mejia J, Sun L, et al. Topological organization of multichromosomal regions by the long intergenic noncoding RNA Firre. Nat Struct Mol Biol (2014) 21(2):198-206. doi:10.1038/nsmb. 2764

163. Lai F, Orom UA, Cesaroni M, Beringer M, Taatjes DJ, Blobel GA, et al. Activating RNAs associate with mediator to enhance chromatin architecture and transcription. Nature (2013) 494(7438):497-501. doi:10.1038/nature11884

164. Orom UA, Derrien T, Beringer M, Gumireddy K, Gardini A, Bussotti G, et al. Long noncoding RNAs with enhancer-like function in human cells. Cell (2010) 143(1):46-58. doi:10.1016/j.cell.2010.09.001

165. Krivega I, Dean A. Enhancer and promoter interactions-long distance calls. Curr Opin Genet Dev (2012) 22(2):79-85. doi:10.1016/j.gde.2011.11.001

166. Kagey MH, Newman JJ, Bilodeau S, Zhan Y, Orlando DA, van Berkum NL, et al. Mediator and cohesin connect gene expression and chromatin architecture. Nature (2010) 467(7314):430-5. doi:10.1038/nature09380

167. O'Shea JJ, Paul WE. Mechanisms underlying lineage commitment and plasticity of helper CD4+ T cells. Science (2010) 327(5969):1098-102. doi:10.1126/ science. 1178334

168. Geginat J, Paroni M, Maglie S, Alfen JS, Kastirr I, Gruarin P, et al. Plasticity of human CD4 T cell subsets. Front Immunol (2014) 5:630. doi:10.3389/fimmu. 2014.00630

169. Hedrich CM, Bream JH. Cell type-specific regulation of IL-10 expression in inflammation and disease. Immunol Res (2010) 47(1-3):185-206. doi:10.1007/ s12026-009-8150-5

170. Chen Z, Tato CM, Muul L, Laurence A, O'Shea JJ. Distinct regulation of interleukin-17 in human T helper lymphocytes. Arthritis Rheum (2007) 56(9):2936-46. doi:10.1002/art.22866

171. Wilson NJ, Boniface K, Chan JR, McKenzie BS, Blumenschein WM, Mattson JD, et al. Development, cytokine profile and function of human interleukin 17producing helper T cells. Nat Immunol (2007) 8(9):950-7. doi:10.1038/ni1497

172. Zhang F, Meng G, Strober W. Interactions among the transcription factors Runx1, RORgammat and Foxp3 regulate the differentiation of interleukin 17producing T cells. Nat Immunol (2008) 9(11):1297-306. doi:10.1038/ni.1663
173. Klunker S, Chong MM, Mantel PY, Palomares O, Bassin C, Ziegler M, et al. Transcription factors RUNX1 and RUNX3 in the induction and suppressive function of Foxp3+ inducible regulatory T cells. J Exp Med (2009) 206(12):2701-15. doi:10.1084/jem.20090596

174. Li L, Patsoukis N, Petkova V, Boussiotis VA. Runx1 and Runx3 are involved in the generation and function of highly suppressive IL-17-producing T regulatory cells. PLoS One (2012) 7(9):e45115. doi:10.1371/journal.pone.0045115

175. Chung Y, Tanaka S, Chu F, Nurieva RI, Martinez GJ, Rawal S, et al. Follicular regulatory $\mathrm{T}$ cells expressing Foxp3 and Bcl-6 suppress germinal center reactions. Nat Med (2011) 17(8):983-8. doi:10.1038/nm.2426

176. Tsuji M, Komatsu N, Kawamoto S, Suzuki K, Kanagawa O, Honjo T, et al. Preferential generation of follicular B helper T cells from Foxp3+ T cells in gut Peyer's patches. Science (2009) 323(5920):1488-92. doi:10.1126/science.1169152

177. Rossi RL, Rossetti G, Wenandy L, Curti S, Ripamonti A, Bonnal RJP, et al. Distinct microRNA signatures in human lymphocyte subsets and enforcement of the naive state in CD4+ T cells by the microRNA miR-125b. Nat Immunol (2011) 12(8):796-803. doi:10.1038/ni.2057

178. Turner M, Galloway A, Vigorito E. Noncoding RNA and its associated proteins as regulatory elements of the immune system. Nat Immunol (2014) 15(6):484-91. doi:10.1038/ni.2887

179. Barabasi A-L, Oltvai ZN. Network biology: understanding the cell's functional organization. Nat Rev Genet (2004) 5(2):101-13. doi:10.1038/nrg1272

180. Zhang B, Arun G, Mao Yuntao S, Lazar Z, Hung G, Bhattacharjee G, et al. The lncRNA Malat1 is dispensable for mouse development but its transcription plays a cis-regulatory role in the adult. Cell Rep (2013) 2(1):111-23. doi:10.1016/j.celrep.2012.06.003

181. Necsulea A, Kaessmann H. Evolutionary dynamics of coding and non-coding transcriptomes. Nat Rev Genet (2014) 15(11):734-48. doi:10.1038/nrg3802

182. Pollard KS, Salama SR, King B, Kern AD, Dreszer T, Katzman S, et al. Forces shaping the fastest evolving regions in the human genome. PLoS Genet (2006) 2(10):e168. doi:10.1371/journal.pgen.0020168

183. Schorderet P, Duboule D. Structural and functional differences in the long noncoding RNA hotair in mouse and human. PLoS Genet (2011) 7(5):e1002071. doi:10.1371/journal.pgen.1002071

184. Gerstein MB, Rozowsky J, Yan KK, Wang D, Cheng C, Brown JB, et al. Comparative analysis of the transcriptome across distant species. Nature (2014) 512(7515):445-8. doi:10.1038/nature13424

185. On T, Xiong X, Pu S, Turinsky A, Gong Y, Emili A, et al. The evolutionary landscape of the chromatin modification machinery reveals lineage specific gains, expansions, and losses. Proteins (2010) 78(9):2075-89. doi:10.1002/prot.22723

186. Hrdlickova B, Kumar V, Kanduri K, Zhernakova D, Tripathi S, Karjalainen J, et al. Expression profiles of long non-coding RNAs located in autoimmune disease-associated regions reveal immune cell-type specificity. Genome Med (2014) 6(10):88. doi:10.1186/s13073-014-0088-0

187. Xia F, Dong F, Yang Y, Huang A, Chen S, Sun D, et al. Dynamic transcription of long non-coding RNA genes during CD4+ T cell development and activation. PLoS One (2014) 9(7):e101588. doi:10.1371/journal.pone.0101588

188. Aoki K, Harashima A, Sano M, Yokoi T, Nakamura S, Kibata M, et al. A thymus-specific noncoding RNA, Thy-ncR1, is a cytoplasmic riboregulator of MFAP4 mRNA in immature T-cell lines. BMC Mol Biol (2010) 11(1):99. doi:10.1186/1471-2199-11-99

189. Hu G, Tang Q, Sharma S, Yu F, Escobar TM, Muljo SA, et al. Expression and regulation of intergenic long noncoding RNAs during $\mathrm{T}$ cell development and differentiation. Nat Immunol (2013) 14(11):1190-8. doi:10.1038/ni.2712

190. Kimura T, Jiang S, Nishizawa M, Yoshigai E, Hashimoto I, Nishikawa M, et al. Stabilization of human interferon-alphal mRNA by its antisense RNA. Cell Mol Life Sci (2013) 70(8):1451-67. doi:10.1007/s00018-012-1216-x

191. Yan M-D, Hong C-C, Lai G-M, Cheng A-L, Lin Y-W, Chuang S-E. Identification and characterization of a novel gene Saf transcribed from the opposite strand of Fas. Hum Mol Genet (2005) 14(11):1465-74. doi:10.1093/hmg/ddi156

192. Sehgal L, Mathur R, Braun FK, Wise JF, Berkova Z, Neelapu S, et al. FASantisense 1 lncRNA and production of soluble versus membrane Fas in B-cell lymphoma. Leukemia (2014) 28(12):2376-87. doi:10.1038/leu.2014.126

193. Haasch D, Chen YW, Reilly RM, Chiou XG, Koterski S, Smith ML, et al. T cell activation induces a noncoding RNA transcript sensitive to inhibition by immunosuppressant drugs and encoded by the proto-oncogene, BIC. Cell Immunol (2002) 217(1-2):78-86. doi:10.1016/S0008-8749(02)00506-3 
194. Liu AY, Torchia BS, Migeon BR, Siliciano RF. The human NTT gene: identification of a novel 17-kb noncoding nuclear RNA expressed in activated CD4+ T cells. Genomics (1997) 39(2):171-84. doi:10.1006/geno.1996.4463

195. Abarrategui I, Krangel MS. Regulation of T cell receptor-alpha gene recombination by transcription. Nat Immunol (2006) 7(10):1109-15. doi:10.1038/ni1379

196. Collier SP, Collins PL, Williams CL, Boothby MR, Aune TM. Cutting edge: influence of Tmevpg1, a long intergenic noncoding RNA, on the expression of Ifng by Th1 cells. J Immunol (2012) 189(5):2084-8. doi:10.4049/jimmunol.1200774

197. Gomez JA, Wapinski OL, Yang YW, Bureau JF, Gopinath S, Monack DM, et al. The NeST long ncRNA controls microbial susceptibility and epigenetic activation of the interferon-gamma locus. Cell (2013) 152(4):743-54. doi:10.1016/j.cell.2013.01.015

198. Zhang H, Nestor CE, Zhao S, Lentini A, Bohle B, Benson M, et al. Profiling of human $\mathrm{CD} 4+\mathrm{T}$-cell subsets identifies the $\mathrm{TH} 2$-specific noncoding RNA GATA3-AS1. J Allergy Clin Immunol (2013) 132(4):1005-8. doi:10.1016/j.jaci. 2013.05.033

199. Seok J, Warren HS, Cuenca AG, Mindrinos MN, Baker HV, Xu W, et al. Genomic responses in mouse models poorly mimic human inflammatory diseases. Proc Natl Acad Sci U S A (2013) 110(9):3507-12. doi:10.1073/pnas.1222878110

200. Takao K, Miyakawa T. Genomic responses in mouse models greatly mimic human inflammatory diseases. Proc Natl Acad Sci US A (2015) 112(4):1167-72. doi:10.1073/pnas.1401965111

201. Tuomela S, Lahesmaa R. Early T helper cell programming of gene expression in human. Semin Immunol (2013) 25(4):282-90. doi:10.1016/j.smim.2013.10.013

202. Necsulea A, Soumillon M, Warnefors M, Liechti A, Daish T, Zeller U, et al. The evolution of lncRNA repertoires and expression patterns in tetrapods. Nature (2014) 505(7485):635-40. doi:10.1038/nature12943

203. Nesterova TB, Slobodyanyuk SY, Elisaphenko EA, Shevchenko AI, Johnston C, Pavlova ME, et al. Characterization of the genomic Xist locus in rodents reveals conservation of overall gene structure and tandem repeats but rapid evolution of unique sequence. Genome Res (2001) 11(5):833-49. doi:10.1101/gr.174901

204. Cabili MN, Trapnell C, Goff L, Koziol M, Tazon-Vega B, Regev A, et al. Integrative annotation of human large intergenic noncoding RNAs reveals global properties and specific subclasses. Genes Dev (2011) 25(18):1915-27. doi:10.1101/gad.17446611

205. Church DM, Goodstadt L, Hillier LW, Zody MC, Goldstein S, She X, et al. Lineage-specific biology revealed by a finished genome assembly of the mouse. PLoS Biol (2009) 7(5):e1000112. doi:10.1371/journal.pbio.1000112

206. Pang KC, Frith MC, Mattick JS. Rapid evolution of noncoding RNAs: lack of conservation does not mean lack of function. Trends Genet (2006) 22(1):1-5. doi:10.1016/j.tig.2005.10.003

207. Carninci P, Kasukawa T, Katayama S, Gough J, Frith MC, Maeda N, et al The transcriptional landscape of the mammalian genome. Science (2005) 309(5740):1559-63. doi:10.1126/science.1112014

208. Ulitsky I, Shkumatava A, Jan Calvin H, Sive H, Bartel David P. Conserved function of lincRNAs in vertebrate embryonic development despite rapid sequence evolution. Cell (2011) 147(7):1537-50. doi:10.1016/j.cell.2011.11.055

209. He S, Liu S, Zhu H. The sequence, structure and evolutionary features of HOTAIR in mammals. BMC Evol Biol (2011) 11:102. doi:10.1186/1471-214811- 102

210. Zhang X, Lian Z, Padden C, Gerstein MB, Rozowsky J, Snyder M, et al A myelopoiesis-associated regulatory intergenic noncoding RNA transcript within the human HOXA cluster. Blood (2009) 113(11):2526-34. doi:10.1182/ blood-2008-06-162164

211. Wright PW, Huehn A, Cichocki F, Li H, Sharma N, Dang H, et al. Identification of a KIR antisense lncRNA expressed by progenitor cells. Genes Immun (2013) 14(7):427-33. doi:10.1038/gene.2013.36
212. Wang P, Xue Y, Han Y, Lin L, Wu C, Xu S, et al. The STAT3-binding long noncoding RNA lnc-DC controls human dendritic cell differentiation. Science (2014) 344(6181):310-3. doi:10.1126/science.1251456

213. Xing Z, Lin A, Li C, Liang K, Wang S, Liu Y, et al. lncRNA directs cooperative epigenetic regulation downstream of chemokine signals. Cell (2014) 159(5):1110-25. doi:10.1016/j.cell.2014.10.013

214. Carpenter S, Aiello D, Atianand MK, Ricci EP, Gandhi P, Hall LL, et al. A long noncoding RNA mediates both activation and repression of immune response genes. Science (2013) 341(6147):789-92. doi:10.1126/science.1240925

215. Rapicavoli NA, Qu K, Zhang J, Mikhail M, Laberge R-M, Chang HY. A mammalian pseudogene lncRNA at the interface of inflammation and anti-inflammatory therapeutics. Elife (2013) 2:e00762. doi:10.7554/eLife. 00762

216. Li Z, Chao T-C, Chang K-Y, Lin N, Patil VS, Shimizu C, et al. The long noncoding RNA THRIL regulates TNF $\alpha$ expression through its interaction with hnRNPL. Proc Natl Acad Sci U S A (2014) 111(3):1002-7. doi:10.1073/pnas. 1313768111

217. Mosmann TR, Cherwinski H, Bond MW, Giedlin MA, Coffman RL. Two types of murine helper T cell clone. I. Definition according to profiles of lymphokine activities and secreted proteins. J Immunol (1986) 136(7):2348-57.

218. Chang S, Aune TM. Histone hyperacetylated domains across the Ifng gene region in natural killer cells and T cells. Proc Natl Acad Sci U S A (2005) 102(47):17095-100. doi:10.1073/pnas.0502129102

219. Zhou W, Chang S, Aune TM. Long-range histone acetylation of the Ifng gene is an essential feature of T cell differentiation. Proc Natl Acad Sci U S A (2004) 101(8):2440-5. doi:10.1073/pnas.0306002101

220. Ho IC, Lo D, Glimcher LH. c-maf promotes T helper cell type 2 (Th2) and attenuates Th1 differentiation by both interleukin 4-dependent and independent mechanisms. J Exp Med (1998) 188(10):1859-66. doi:10.1084/ jem.188.10.1859

221. Liu X, Nurieva RI, Dong C. Transcriptional regulation of follicular T-helper (Tfh) cells. Immunol Rev (2013) 252(1):139-45. doi:10.1111/imr.12040

222. Sato K, Miyoshi F, Yokota K, Araki Y, Asanuma Y, Akiyama Y, et al. Marked induction of c-Maf protein during Th17 cell differentiation and its implication in memory Th cell development. J Biol Chem (2011) 286(17):14963-71. doi:10.1074/jbc.M111.218867

223. Gupta RA, Shah N, Wang KC, Kim J, Horlings HM, Wong DJ, et al. Long noncoding RNA HOTAIR reprograms chromatin state to promote cancer metastasis. Nature (2010) 464(7291):1071-6. doi:10.1038/nature08975

Conflict of Interest Statement: The authors declare that the research was conducted in the absence of any commercial or financial relationships that could be construed as a potential conflict of interest.

Received: 22 January 2015; accepted: 28 March 2015; published online: 15 April 2015. Citation: Panzeri I, Rossetti G, Abrignani S and Pagani M (2015) Long intergenic non-coding RNAs: novel drivers of human lymphocyte differentiation. Front. Immunol. 6:175. doi: 10.3389/fimmu.2015.00175

This article was submitted to T Cell Biology, a section of the journal Frontiers in Immunology.

Copyright (C) 2015 Panzeri, Rossetti, Abrignani and Pagani. This is an open-access article distributed under the terms of the Creative Commons Attribution License (CC $B Y)$. The use, distribution or reproduction in other forums is permitted, provided the original author(s) or licensor are credited and that the original publication in this journal is cited, in accordance with accepted academic practice. No use, distribution or reproduction is permitted which does not comply with these terms. 